\title{
$N$-methyl-D-aspartate receptors mediate activity- dependent down-regulation of potassium channel genes during the expression of homeostatic intrinsic plasticity
}

Kwan Young Lee ${ }^{1 \dagger}$, Sara E Royston ${ }^{2,3 \dagger}$, Max O Vest ${ }^{1}$, Daniel J Ley ${ }^{1}$, Seungbae Lee ${ }^{1}$, Eric C Bolton ${ }^{1}$ and Hee Jung Chung ${ }^{1,2^{*}}$

\begin{abstract}
Background: Homeostatic intrinsic plasticity encompasses the mechanisms by which neurons stabilize their excitability in response to prolonged and destabilizing changes in global activity. However, the milieu of molecular players responsible for these regulatory mechanisms is largely unknown.

Results: Using whole-cell patch clamp recording and unbiased gene expression profiling in rat dissociated hippocampal neurons cultured at high density, we demonstrate here that chronic activity blockade induced by the sodium channel blocker tetrodotoxin leads to a homeostatic increase in action potential firing and down-regulation of potassium channel genes. In addition, chronic activity blockade reduces total potassium current, as well as protein expression and current of voltage-gated $K_{v} 1$ and $K_{v} 7$ potassium channels, which are critical regulators of action potential firing. Importantly, inhibition of N-Methyl-D-Aspartate receptors alone mimics the effects of tetrodotoxin, including the elevation in firing frequency and reduction of potassium channel gene expression and current driven by activity blockade, whereas inhibition of L-type voltage-gated calcium channels has no effect.

Conclusions: Collectively, our data suggest that homeostatic intrinsic plasticity induced by chronic activity blockade is accomplished in part by decreased calcium influx through N-Methyl-D-Aspartate receptors and subsequent transcriptional down-regulation of potassium channel genes.
\end{abstract}

Keywords: Homeostatic intrinsic plasticity, Potassium channel, NMDA receptor, Action potential, Hippocampus

\section{Background}

Chronic perturbations in neuronal activity trigger homeostatic intrinsic plasticity, which maintain neuronal excitability within physiologic boundaries [1]. For example, action potential (AP) firing frequency is elevated by chronic activity blockade in cultured hippocampal and cortical neurons [2-6] and in hippocampus in vivo [7]. Conversely, chronic activity enhancement leads to a

\footnotetext{
* Correspondence: chunghj@life.illinois.edu

${ }^{\dagger}$ Equal contributors

'Department of Molecular and Integrative Physiology, University of Illinois at Urbana-Champaign, 407 South Goodwin Avenue, 524 Burrill Hall, Urbana, IL 61801, USA

${ }^{2}$ Program in Neuroscience Program, University of Illinois at

Urbana-Champaign, Urbana, Illinois 61801, USA

Full list of author information is available at the end of the article
}

reduction in AP firing rate $[2,5,8]$. The elevation in AP firing frequency induced by global activity suppression is coupled to elevated sodium $\left(\mathrm{Na}^{+}\right)$current density and reduced potassium $\left(\mathrm{K}^{+}\right)$current density in dissociated cortical neurons [4], implicating activity-dependent changes in ionic conductance in homeostatic intrinsic plasticity. Intrinsic firing properties of mammalian neurons are largely determined by the biophysical properties, spatial distribution, and abundance of ion channels at the plasma membrane [9]. However, the identity of the specific channels critical for homeostatic intrinsic plasticity remains largely unknown.

Recent studies have reported that long-term changes in intracellular calcium $\left(\mathrm{Ca}^{2+}\right)$ concentration can regulate expression of multiple ion channels [10] and mediate 
homeostatic plasticity in response to chronic alterations in neuronal activity [2,11-15]. In particular, prolonged inhibition of $\mathrm{Ca}^{2+}$ influx through $N$-Methyl-D-aspartate receptors (NMDAR) but not L-type voltage-gated $\mathrm{Ca}^{2+}$ channels (VGCC) has been shown to mimic the elevation in firing frequency driven by chronic activity blockade [2]. Interestingly, inhibition of transcription blocks induction of homeostatic plasticity at excitatory synapses in cultured cortical and hippocampal neurons [11,14], suggesting a critical role for transcriptional regulation of gene expression in homeostatic plasticity. Furthermore, the computational modeling work has recently shown that activity-dependent regulation of ion channel transcripts can underlie a mechanism by which alterations in intracellular $\mathrm{Ca}^{2+}$ concentration can control neuronal homeostasis [16]. Since $\mathrm{Ca}^{2+}$ influx through NMDARs or L-type VGCCs stimulates activity-dependent transcription in neurons [17], we hypothesized that homeostatic intrinsic plasticity is mediated in part by activity-dependent expression of genes whose protein products regulate intrinsic properties of neurons.

In the present study, we used unbiased gene expression profiling, real-time quantitative polymerase chain reaction (QPCR), and electrophysiology to search for novel molecular players critical for modulating ionic currents during the induction of homeostatic intrinsic plasticity in high-density cultures of dissociated hippocampal neurons. We identified 873 activity-dependent transcripts whose protein products have not previously been implicated in homeostatic plasticity. We found that chronic activity blockade leads to an increase in firing frequency, and decreases in $\mathrm{K}^{+}$current and gene expression of various $\mathrm{K}^{+}$channels. Furthermore, we discovered that the observed homeostatic intrinsic plasticity and down-regulation of $\mathrm{K}^{+}$channel genes are mediated by changes in NMDAR activity but not Ltype VGCC activity.

\section{Results and discussion}

Chronic activity blockade induces a homeostatic increase in intrinsic excitability

To collect ample amounts of RNA for cDNA microarray analysis, high-density cultures of dissociated hippocampal neurons (330 neurons $/ \mathrm{cm}^{2}$ ) were treated for 48 hours (h) with vehicle control $\left(\mathrm{CTL}-\mathrm{H}_{2} \mathrm{O}, 0.1 \% \mathrm{H}_{2} \mathrm{O}\right)$, the sodium channel blocker tetrodotoxin (TTX, 0.5-1 $\mu \mathrm{M}$ ), or the $\mathrm{GABA}_{\mathrm{A}}$ receptor antagonist bicuculine $(\mathrm{BC}, 20 \mu \mathrm{M})$ (Figure 1A). Application of TTX immediately blocked spontaneous activity of hippocampal neurons whereas BC application rapidly induced burst firing of action potentials compared to $\mathrm{CTL}-\mathrm{H}_{2} \mathrm{O}$ (Additional file 1: Figure S1). To verify the induction of homeostatic intrinsic plasticity, AP firing frequency was measured immediately after TTX or $\mathrm{BC}$ was washed out from the neurons treated for $48 \mathrm{~h}$ with TTX or BC as previously described [2] (Figure 1A,B).

TTX treatment for $48 \mathrm{~h}$ significantly increased AP firing frequency compared to CTL treatment at $40 \mathrm{pA}$ injection $(p<0.05)$ and for all current injections over 60 $\mathrm{pA}$ in hippocampal neurons cultured at high density (Figure $1 \mathrm{~A}, \mathrm{~B}, p<0.01$ ). The mean AP firing frequency in the TTX-treated neurons induced by $100 \mathrm{pA}$ current injection was $32.4 \pm 1.5 \mathrm{~Hz}$, a $35 \%$ increase compared to CTL- $\mathrm{H}_{2} \mathrm{O}$ neurons $(23.9 \pm 2.1 \mathrm{~Hz}, p<0.01)$. In contrast, $48 \mathrm{~h} \mathrm{BC}$ treatment significantly reduced AP firing rates at $80-90 \mathrm{pA}$ injections but did not alter firing rates for all other current injections (Figure 1A,B). Although membrane capacitance and resting membrane potential were unaffected by TTX or BC treatment (Table 1), TTX treatment increased the input resistance (Table 1)
A

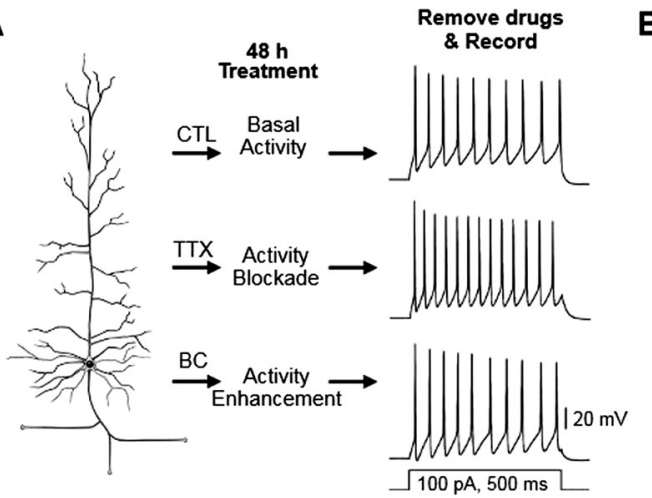

B

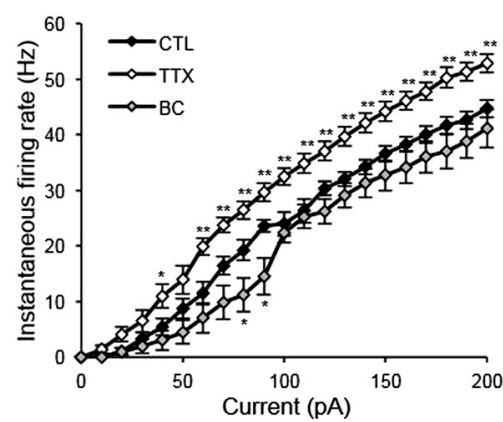

Figure 1 Chronic blockade of neuronal activity induces a homeostatic increase in intrinsic excitability. (A,B) Whole-cell patch clamp recording of rat dissociated hippocampal neurons cultured in a high density (DIV 12-14) that were treated for $48 \mathrm{~h}$ with vehicle control (CTL- $\mathrm{H}_{2} \mathrm{O}$, $\left.0.1 \% \mathrm{H}_{2} \mathrm{O}\right)$, TTX $(0.5-1 \mu \mathrm{M})$, or $\mathrm{BC}(20 \mu \mathrm{M})$. Following treatment removal, spike trains were evoked in pyramidal neurons by delivering constant somatic current pulses for $500 \mathrm{~ms}$ duration at a resting potential of $-60 \mathrm{mV}$. (A) Representative spike trains. (B) Average AP firing rates (Hz) measured in pyramidal neurons treated for $48 \mathrm{~h}$ with $C T L-H_{2} O(n=13)$, TTX $(n=10)$, or $B C(n=9)$. TTX but not $B C$ treatment for $48 \mathrm{~h}$ significantly increased AP firing frequency compared to $\mathrm{CTL}-\mathrm{H}_{2} \mathrm{O}$ treatment. Mean $\pm \mathrm{SEM}\left({ }^{*} p<0.05\right.$, $\left.{ }^{* *} p<0.01\right)$. 
Table 1 Passive properties of hippocampal pyramidal neurons cultured at high density following $\mathbf{4 8 ~} \mathrm{h}$ pharmacological treatment

\begin{tabular}{lllll}
\hline Treatment & $\boldsymbol{n}$ & $\boldsymbol{C}_{\mathbf{m}}(\mathbf{p F})$ & $\boldsymbol{R}_{\mathbf{i n}}(\mathbf{M} \Omega)$ & $\boldsymbol{V}_{\mathbf{m}}(\mathbf{m V})$ \\
\hline CTL- $\mathrm{H}_{2} \mathrm{O}$ & 31 & $48.8 \pm 1.2$ & $571 \pm 34$ & $-59.5 \pm 0.6$ \\
TTX & 20 & $47.1 \pm 1.9$ & $721 \pm 44^{*}$ & $-59.8 \pm 0.9$ \\
$\mathrm{BC}$ & 9 & $48.0 \pm 3.4$ & $529 \pm 53$ & $-60.1 \pm 1.7$ \\
$\mathrm{APV}$ & 9 & $45.0 \pm 1.8$ & $787 \pm 51^{*, \#}$ & $-58.0 \pm 2.1$ \\
TTX+ APV & 10 & $50.7 \pm 2.4$ & $791 \pm 22^{* *, \#}$ & $-58.7 \pm 0.8$ \\
TTX+ Nif & 9 & $47.4 \pm 3.1$ & $769 \pm 22^{*, \#}$ & $-58.1 \pm 0.6$ \\
CTL-DMSO & 12 & $49.3 \pm 1.5$ & $583 \pm 32$ & $-60.5 \pm 0.9$ \\
Nif & 9 & $46.8 \pm 2.3$ & $672 \pm 43$ & $-58.7 \pm 0.5$ \\
STO-609 & 10 & $50.2 \pm 2.0$ & $680 \pm 63$ & $-60.7 \pm 0.8$ \\
\hline
\end{tabular}

$n$, number; $C \mathrm{~m}$, Whole-cell membrane capacitance; $R$ in, input resistance; $V \mathrm{~m}$, resting membrane potential. Each value represents the mean \pm SEM ${ }^{*} p<0.05$, ${ }^{* *} p<0.01$ for $\mathrm{CTL}^{-} \mathrm{H}_{2} \mathrm{O}$ vs. drug treatment; ${ }^{*} p<0.05$ for $\mathrm{BC}$ vs. other drug treatment).

and decreased fast after-hyperpolarization (fAHP) amplitude and AP latency compared to CTL- $\mathrm{H}_{2} \mathrm{O}$ treatment (Table 2). Taken together, these findings indicate that TTX treatment for $48 \mathrm{~h}$ but not BC treatment caused an increase in AP firing rates in hippocampal neurons cultured at high density.

Microarray analysis reveals that chronic alteration of network activity regulates genes involved in hippocampal synaptic and intrinsic membrane properties

Quadruplicate RNA samples for each treatment were subjected to cDNA microarray analysis (41,012 total gene probes). Gene expression profiling in high-density cultures composed primarily of glutamatergic neurons (Figure 2A) revealed 901 transcripts, which were significantly regulated by prolonged activity manipulation
(Figure 2B). Consistent with previous studies reporting that alterations in intracellular $\mathrm{Ca}^{2+}$ concentration are required for homeostatic regulation of synaptic and intrinsic neuronal properties [2,11,13-15,18], we found that genes classified using the Gene Ontology (GO) terms "synaptic transmission", "transmission of nerve impulses", and "cytosolic $\mathrm{Ca}^{2+}$ ion homeostasis" were significantly over-represented in "chronic activity"-regulated gene transcripts (Table 3). The enriched GO classes also included development, behavior, and signaling pathways (Table 3), underscoring the complex impact that prolonged activity alteration exerts on gene regulation.

Of these "chronic activity"-regulated gene transcripts, we identified 873 genes, which were not previously implicated in homeostatic plasticity (Figure 2B,C). Of these transcripts, the GO theme " $\mathrm{K}^{+}$ion transport" was strikingly over-represented (Table 3). TTX treatment decreased mRNA levels for 14 of $15 \mathrm{~K}^{+}$channel genes, whose protein products encode the principle and auxiliary subunits for $\mathrm{K}_{\mathrm{v}} 1$ channels (KCNA4, KCNAB3 and LGI1), $\mathrm{K}_{\mathrm{v}} 2.1$ channels (KCNS3 and KCNV1), $\mathrm{K}_{\mathrm{v}} 4$ channels (KCNIP1 and KCNIP3), $\mathrm{K}_{\mathrm{v}} 7$ channels (KCNQ3), HERG channels $(\mathrm{KCNH} 7)$, hyperpolarization-activated cyclic nucleotidegated non-selective cation $\mathrm{HCN}$ channels (HCN1), $\mathrm{Ca}^{2+}$-activated large conductance BK channels (KCNMB2), $\mathrm{Ca}^{2+}$ activated small conductance SK channels (KCNN1), TRAAK leak $\mathrm{K}^{+}$channels (KCNK4), and THIK2 leak $\mathrm{K}^{+}$channels (KCNK12) (Figure 2C).

Conversely, BC treatment increased mRNA levels of genes whose protein products encode $\mathrm{K}_{\mathrm{v}} 1$ channels (KCNA1, KCNA4, LGI1), BK channels (KCNMB2), TREK1 leak $\mathrm{K}^{+}$channels (KCNK2), and delayed rectifier $\mathrm{K}^{+}$channels (KCNF1) (Figure 2C). Transcripts of the genes that encode negative regulators of $\mathrm{BK}$ and $\mathrm{K}_{\mathrm{v}} 2.1$ channels (KCNJ12, KCNG3, and KCNMB4) were decreased by $\mathrm{BC}$ application (Figure $2 \mathrm{C}$ ). Since $\mathrm{K}^{+}$channels provide a

Table 2 AP properties of hippocampal pyramidal neurons cultured at high density following 48 h pharmacological treatment

\begin{tabular}{|c|c|c|c|c|c|c|c|}
\hline Treatment & $V_{\top}(\mathrm{mV})$ & AP height (mV) & AP rise (ms) & AP decay (ms) & AP HW (ms) & fAHP $(\mathrm{mV})$ & AP latency (ms) \\
\hline $\mathrm{CTL}-\mathrm{H}_{2} \mathrm{O}$ & $-39.4 \pm 0.5$ & $64.6 \pm 1.3$ & $0.70 \pm 0.03$ & $1.72 \pm 0.07$ & $1.94 \pm 0.07$ & $-19.1 \pm 0.6$ & $15.1 \pm 0.72$ \\
\hline$\pi \mathrm{TX}$ & $-40.2 \pm 0.7$ & $67.4 \pm 1.5$ & $0.67 \pm 0.03$ & $1.81 \pm 0.08$ & $1.97 \pm 0.10$ & $-15.4 \pm 0.7^{* *}$ & $11.2 \pm 0.58^{* *}$ \\
\hline $\mathrm{BC}$ & $-37.6 \pm 0.4$ & $65.4 \pm 2.5$ & $0.60 \pm 0.03$ & $1.48 \pm 0.14$ & $1.55 \pm 0.10$ & $-19.7 \pm 1.4^{\#}$ & $14.5 \pm 0.87$ \\
\hline APV & $-38.7 \pm 1.5$ & $65.6 \pm 3.2$ & $0.89 \pm 0.05^{*, \# \#, \wedge \wedge}$ & $2.52 \pm 0.17^{* *, \# \#, \wedge \wedge}$ & $2.56 \pm 0.07^{* *, \# \#, \wedge \wedge}$ & $-11.5 \pm 1.1^{* *_{,} \wedge \wedge}$ & $12.9 \pm 1.12$ \\
\hline$T T X+A P V$ & $-39.9 \pm 0.7$ & $62.8 \pm 2.2$ & $0.70 \pm 0.02$ & $1.92 \pm 0.12^{\$}$ & $2.18 \pm 0.12^{\wedge}$ & $-15.8 \pm 0.9$ & $12.3 \pm 0.78$ \\
\hline TTX + Nif & $-38.4 \pm 0.7$ & $63.5 \pm 2.3$ & $0.62 \pm 0.05^{\$ \$}$ & $1.78 \pm 0.13^{\$ \$}$ & $2.04 \pm 0.16$ & $-17.6 \pm 1.2^{\$ \$}$ & $11.0 \pm 0.54^{*}$ \\
\hline CTL-DMSO & $-39.0 \pm 0.9$ & $66.5 \pm 1.4$ & $0.76 \pm 0.07$ & $1.73 \pm 0.19$ & $2.04 \pm 0.11$ & $-17.9 \pm 1.5$ & $16.1 \pm 1.5$ \\
\hline Nif & $-38.0 \pm 0.7$ & $68.2 \pm 3.2$ & $0.69 \pm 0.05$ & $1.92 \pm 0.13$ & $2.07 \pm 0.12$ & $-17.5 \pm 0.8$ & $16.9 \pm 1.0$ \\
\hline STO-609 & $-40.0 \pm 0.9$ & $69.3 \pm 1.4$ & $0.78 \pm 0.05$ & $2.14 \pm 0.12$ & $2.26 \pm 0.13$ & $-15.9 \pm 0.9$ & $16.8 \pm 2.0$ \\
\hline
\end{tabular}

$V T$, voltage threshold for action potential; AP, Action potential; rise, 10-90\% rise time of AP; decay, 10-90\% decay time of AP; HW, half-width; fAHP, fast afterhyperpolarization. AP properties were measured from the first action potential evoked by a current step to $100 \mathrm{pA}$ at a holding potential of $-60 \mathrm{mV}$. Each value represents the mean \pm SEM $\left({ }^{*} p<0.05,{ }^{* *} p<0.01\right.$ for $C T L-\mathrm{H}_{2} \mathrm{O}$ vs. drug treatment; ${ }^{\#} p<0.05,{ }^{\# \#} p<0.01$ for $\mathrm{TTX}$ vs. other drug treatment; ${ }^{\wedge} p<0.05,{ }^{\wedge} p<0.01$ for $\mathrm{BC}$ vs. other drug treatment; ${ }^{\$} p<0.05,{ }^{\$} p<0.01$ for APV vs. other drug treatment). 
A

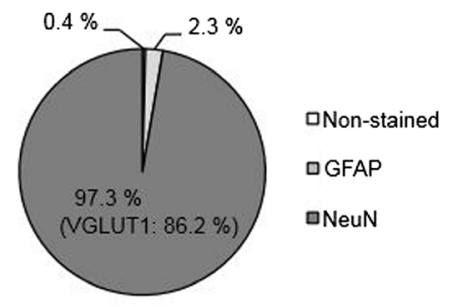

C

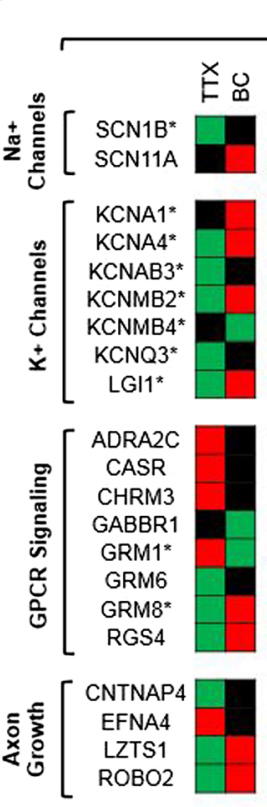

No Change

Expression Decrease

Expression Increase
Axon

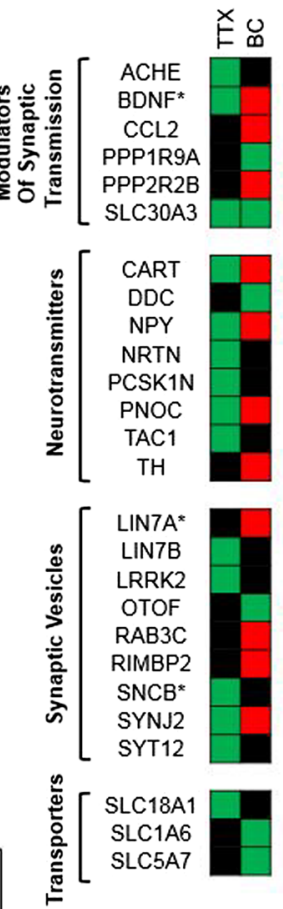

B

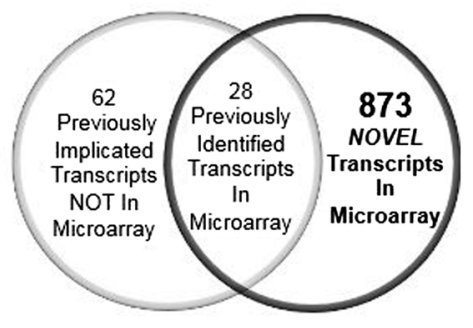

Soma and Dendrites

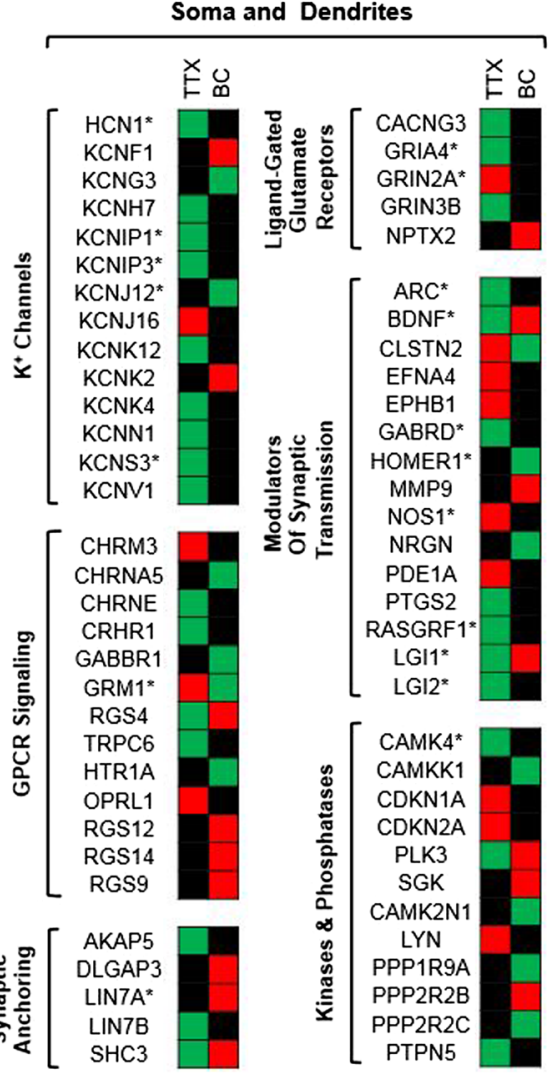

Figure $\mathbf{2}$ Chronic activity alterations regulate genes involved in hippocampal synaptic and intrinsic membrane properties. (A) Pie chart showing the relative proportion of neurons and glia in rat dissociated hippocampal neuronal culture. Immunostaining studies revealed that $2.3 \pm 2.1 \%$ of cells expressed glial marker, glial fibrillary acid protein (GFAP) whereas $97.3 \pm 2.9 \%$ were positive for the neuronal marker NeuN. Of the NeuN-positive cells, $86.2 \pm 5.0 \%$ were immunoreactive for vesicular glutamate transporter 1 (VGLUT1) indicative of glutamatergic neurons. (B) Venn diagram showing 901 transcripts identified by microarray analysis whose expression were significantly changed by $48 \mathrm{~h}$ TTX and $\mathrm{BC}$ treatment compared to $\mathrm{CTL}-\mathrm{H}_{2} \mathrm{O}$ treatment at $48 \mathrm{~h}$ using an FDR $<0.05$ and a fold change $<0.667$ (repressed) or $>1.5$ (induced) (black circle). The genes whose protein products have previously been implicated in homeostatic plasticity are also indicated (gray circle). (C) The colormetric representation shows select genes, indicated by HUGO Gene Nomenclature gene symbols, whose transcripts were repressed (green) and induced (red). The *denotes genes that further tested for activity-dependent changes in their mRNA levels using QPCR analysis. Using Gene Ontology analysis, select activity-regulated genes were grouped by cellular components, molecular function, and biological processes.

main driving force for membrane hyperpolarization that dampens intrinsic excitability [9], these results suggest that down-regulation of multiple $\mathrm{K}^{+}$channel genes may contribute to the TTX-induced rise in intrinsic excitability whereas BC-induced dampening of intrinsic excitability at 80-90 pA injections (Figure 1B) may be achieved in part by enhanced outward $\mathrm{K}^{+}$current through $\mathrm{K}_{\mathrm{v}} 1, \mathrm{~K}_{\mathrm{v}} 2.1$, or BK channels.

Our microarray analyses have also revealed novel synaptic genes whose protein products have not been implicated in homeostatic plasticity including GRM8, LGI2, LIN7A, $N O S 1, S N C B$, and GABRD (Figure 2B,C). Of particular 


\begin{tabular}{|c|c|c|}
\hline \multirow[t]{2}{*}{ GO biological processes } & \multicolumn{2}{|l|}{$P$-values } \\
\hline & TTX & BC \\
\hline Cell-cell signaling & $7.40 e^{-6}$ & $1.60 e^{-4}$ \\
\hline Transmission of nerve impulse & $4.60 e^{-5}$ & $2.00 e^{-4}$ \\
\hline Synaptic transmission & $1.00 \mathrm{e}^{-5}$ & $4.50 \mathrm{e}^{-4}$ \\
\hline Neuropeptide signaling pathway & $4.80 e^{-5}$ & $1.40 e^{-2}$ \\
\hline Intracellular signaling cascade & $5.70 e^{-9}$ & $2.90 e^{-8}$ \\
\hline Cytosolic $\mathrm{Ca}^{2+}$ ion homeostasis & $4.90 e^{-8}$ & $4.70 e^{-3}$ \\
\hline Regulation of phosphorylation & $1.00 e^{-5}$ & $9.60 e^{-2}$ \\
\hline Second-messenger-mediated signaling & $1.30 e^{-5}$ & $2.90 e^{-4}$ \\
\hline CAMP-mediated signaling & $4.60 e^{-3}$ & $1.10 \mathrm{e}^{-2}$ \\
\hline Ion transport & $4.90 e^{-4}$ & $5.60 e^{-2}$ \\
\hline $\mathrm{K}^{+}$ion transport & $2.40 e^{-5}$ & $4.60 \mathrm{e}^{-2}$ \\
\hline Metal ion transport & $2.10 e^{-4}$ & $3.50 \mathrm{e}^{-2}$ \\
\hline Nervous system development & $2.10 e^{-5}$ & $1.10 \mathrm{e}^{-2}$ \\
\hline Neuron differentiation & $7.70 e^{-4}$ & $1.80 \mathrm{e}^{-2}$ \\
\hline Neuron development & $8.20 e^{-4}$ & $1.80 \mathrm{e}^{-2}$ \\
\hline Axon Guidance & N/A & $9.30 \mathrm{e}^{-3}$ \\
\hline Behavior & $1.80 \mathrm{e}^{-7}$ & $5.10 e^{-6}$ \\
\hline Learning or memory & $4.30 e^{-5}$ & $3.30 e^{-4}$ \\
\hline Regulation of synaptic plasticity & $7.10 e^{-4}$ & N/A \\
\hline
\end{tabular}

interest, neuronal nitric oxide synthase (nNOS) produces NO upon stimulation of NMDARs [19]. Since NO is required for the induction of long-term potentiation at excitatory synapses [20], TTX-induced NOS1 expression (Figure 2C) could increase synaptic strength during the expression of homeostatic plasticity. Considering the potent roles of presynaptic mGluR8 in suppressing glutamate release in the hippocampus [21] as well as Lin7A and $\alpha$ synuclein in synaptic vesicle exocytosis [22-25], the modulation of GRM8, LIN7A, and SNCB expression by chronic activity alteration (Figure $2 \mathrm{C}$ ) may be involved in presynaptic expression of homeostatic synaptic scaling [13,26-28].

The chronic activity-regulated gene transcripts included 28 genes whose protein products have previously been implicated in homeostatic plasticity (Figure 2B), including $A R C$ [29], BDNF [3,30-32], NPTX2 [33], GRIA4 [33], HOMER1 [34], RASGRF1 [35] and CAMK4 [11,14]. Consistent with TTX-induced decreases in $A R C$ and HOMER1 mRNAs (Figure $2 \mathrm{C}$ ), synaptic scaling induced by chronic inactivity is mediated by diminished Arc/Arg3.1 [29] and Homer1a [34]. Interestingly, although prolonged activity enhancement reduces the localization of RasGRF1 and surface GluA1 at the proximal dendrites of hippocampal cultured neurons [35], we discover that TTX but not BC treatment reduced RASGRF1 mRNAs.
Not identified by our microarray were at least 62 transcripts whose protein products have previously been implicated in homeostatic plasticity (Figure 2B). Previous studies have reported that dendritic local protein synthesis is required for synaptic scaling induced by chronic treatment with TTX and APV [36] whereas prolonged inhibition of the ubiquitin proteasome system has been shown to mimic synaptic scaling induced by chronic activity blockade in cultured hippocampal neurons [37]. Recently, chronic inactivity-induced degradation of PICK1 is reported to enhance surface expression of GluA2-containing AMPARs during the expression of synaptic scaling in cultured cortical neurons [38]. These studies suggest that homeostatic plasticity involves additional posttranscriptional regulatory mechanisms that influence protein synthesis and degradation.

\section{Chronic inhibition of NMDARs drives a homeostatic} increase in intrinsic excitability and down-regulation of $\mathrm{K}^{+}$ channel genes

$\mathrm{Ca}^{2+}$ influx through either NMDARs or L-type VGCCs activates activity-dependent signaling cascades that regulate the activity of transcriptional regulators, which in turn modulate the expression of gene products important for neural development and plasticity [17]. We have previously reported that prolonged inhibition of NMDARs but not L-type VGCCs leads to a homeostatic increase in intrinsic excitability in low-density hippocampal neuronal culture [2]. Similarly, $48 \mathrm{~h}$ treatment with NMDAR antagonist APV $(100 \mu \mathrm{M})$ significantly increased AP firing rates compared to CTL- $\mathrm{H}_{2} \mathrm{O}$ treatment for all current injections over $20 \mathrm{pA}$ in hippocampal neurons cultured at high density $\left(100 \mathrm{pA}, \mathrm{CTL}-\mathrm{H}_{2} \mathrm{O}: 26.7 \pm 1.6 \mathrm{~Hz}, \mathrm{APV}: 34.6 \pm 0.7 \mathrm{~Hz}\right.$, $p<0.01$ ) (Figure 3A,B). $48 \mathrm{~h}$ APV treatment altered AP rise time, decay time, and half width of hippocampal neurons at $100 \mathrm{pA}$ injection (Table 2), but did not affect their membrane capacitance and resting membrane potential (Table 1).

Similar to TTX treatment, $48 \mathrm{~h}$ APV application significantly increased the input resistance (Table 1) and decreased average rheobase current compared to CTL$\mathrm{H}_{2} \mathrm{O}$ treatment (Additional file 2: Table S1). Since a change in input resistance could conceivably affect excitability, the AP firing rates were recalculated in response to current injections from rheobase to rheobase +100 pA as previously described [39]. These results revealed that $48 \mathrm{~h}$ TTX treatment increased AP firing frequency compared to CTL- $\mathrm{H}_{2} \mathrm{O}$ treatment for all current injections over $70 \mathrm{pA}$ from the rheobase current (Additional file 3: Figure S2A, $p<0.05)$. Similarly, APV application significantly increased AP firing rates compared to CTL treatment for all current injections over $50 \mathrm{pA}$ from the rheobase current (Additional file 3: Figure S2A, $p<0.05$ ). 
A

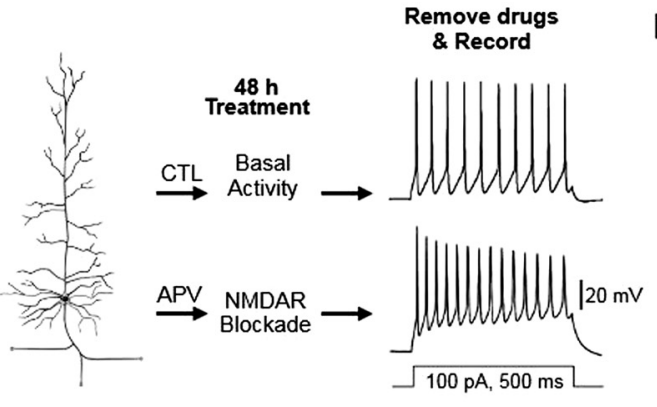

B

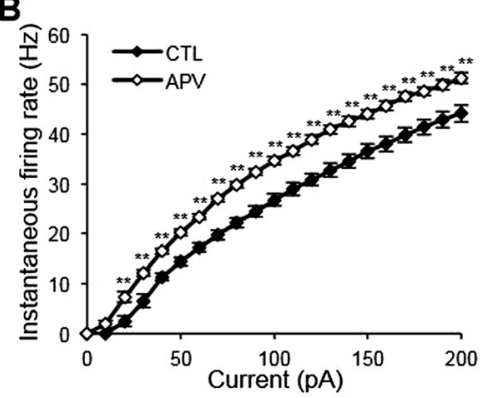

$\mathbf{C}$

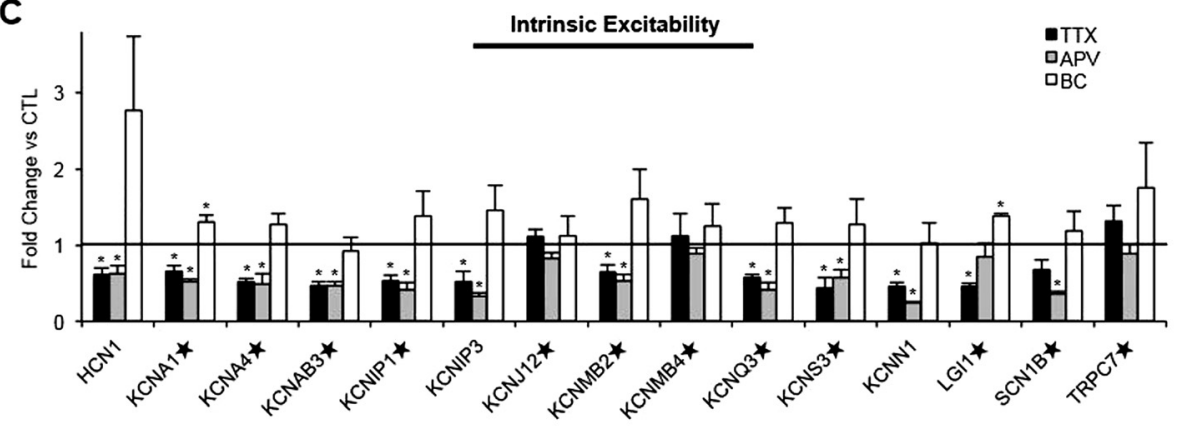

D

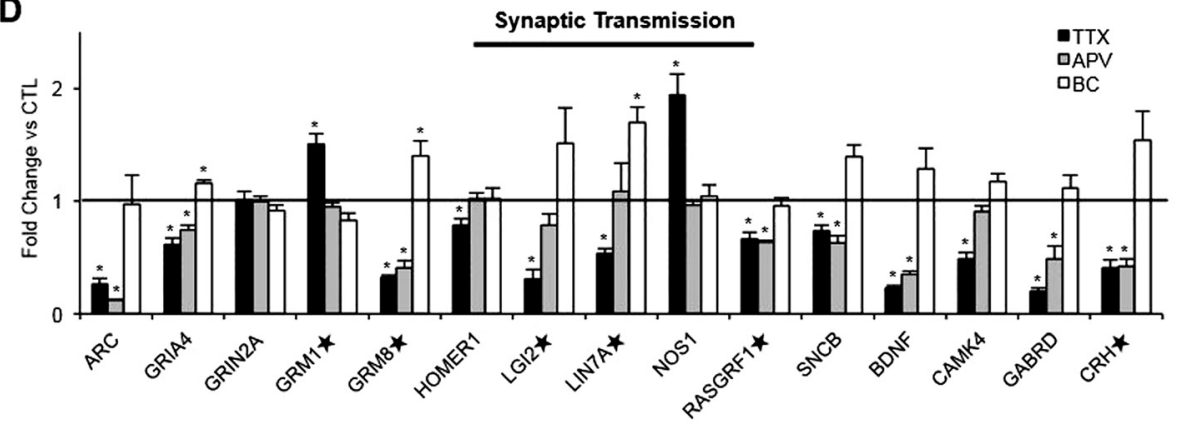

Figure 3 Chronic activity blockade or prolonged NMDAR inhibition reduces gene expression of $\mathrm{K}^{+}$channels. $(\mathrm{A}, \mathrm{B})$ Rat dissociated hippocampal neurons cultured at high density (DIV 12-14) were treated with the NMDAR antagonist APV (100 $\mu M$ ) or control (CTL- $\mathrm{H}_{2} \mathrm{O}, 0.1 \%$ $\mathrm{H}_{2} \mathrm{O}$ ) for $48 \mathrm{~h}$. (A) Representative spike trains are shown. (B) Average AP firing rates ( $\mathrm{Hz}$ ) measured in pyramidal neurons treated for $48 \mathrm{~h}$ with $\mathrm{CTL}-\mathrm{H}_{2} \mathrm{O}(\mathrm{n}=9)$ or APV $(n=9)$ for $48 \mathrm{~h}$. APV treatment significantly increased AP firing frequency compared to $C T L-\mathrm{H}_{2} \mathrm{O}$ treatment. (C,D) QPCR validation of select genes involved in intrinsic excitability (C) and synaptic transmission (D) identified by microarray analysis $(n=5$ per treatment). The mRNA levels of all samples were normalized to the housekeeping gene GAPDH, which was unaffected by these treatments. Following normalization to GAPDH cDNA levels, the relative fold change for each treatment compared to reference control was determined and has been shown. Treatment with TTX or APV decreased the mRNA levels of most of the tested $\mathrm{K}^{+}$channel genes. In contrast, BC application had no effect on most $\mathrm{K}^{+}$channel genes except for KCNA1 and $L G / 1$ which were up-regulated. The $\star$ denotes genes whose protein products have not previously been implicated in homeostatic plasticity. Mean $\pm \operatorname{SEM}\left({ }^{*} p<0.05,{ }^{* *} p<0.01\right)$.

Taken together, these findings indicate that chronic blockade of NMDAR increases the intrinsic excitability of hippocampal neurons, which is not dependent on an increase in input resistance.

The remarkably similar effect on AP firing rates elicited by either TTX or APV treatment (Figures 1, 3A,B, Additional file 3: Figure S2A) led us to postulate that similar gene cohorts were regulated by these treatments. Indeed, QPCR revealed that $48 \mathrm{~h}$ treatment with TTX or APV significantly decreased the mRNA levels of $\mathrm{K}^{+}$channel genes including HCN1, KCNA1, KCNA4, KCNAB3, KCNIP1, KCNIP3, KCNMB2, KCNQ3, KCNS3, and KCNN1 (Figure 3C). LGI1 mRNA expression was reduced by TTX treatment but not APV treatment (Figure 3C). Consistent with our data that BC application for $48 \mathrm{~h}$ has little or no effect on AP firing rate (Figure 1), BC treatment did not alter the mRNA levels of most $\mathrm{K}^{+}$channel genes except for KCNA1 and LGI1 which were increased (Figure 3C). Neither TTX nor BC treatment affected the mRNA level of Glyceraldhyde-3phosphate dehydrogenase $(G A P D H)$ gene, which serves as a control gene for these treatments. These results together suggest that transcriptional down-regulation of $\mathrm{K}^{+}$channel genes by NMDAR signaling may mediate a 
homeostatic rise in intrinsic excitability in response to chronic activity blockade.

Although chronic TTX treatment has been shown to increase average amplitude of $\mathrm{Na}^{+}$currents in dissociated cortical neurons [4], microarray analysis identified only two $\mathrm{Na}^{+}$channel genes, SCN1B and SCN11A, that were regulated by prolonged activity manipulation (Figure $2 \mathrm{C}$ ). QPCR verification revealed that $S C N 1 B$ mRNA was significantly decreased by APV treatment $(p<0.05)$, but not TTX treatment (Figure 3C). SCN1B encodes the $\beta 1$ regulatory subunit $\left(\mathrm{Na}_{\mathrm{v}} 1 \beta\right)$, which modulates current density and subcellular localization of voltage-gated $\mathrm{Na}^{+}$channels [40]. Interestingly, $\mathrm{Na}_{\mathrm{v}} 1 \beta$ was also shown to bind to $\mathrm{K}_{\mathrm{v}} 4.2$ and increase current densities of $\mathrm{K}_{\mathrm{v}} 4.2$ channels [41]. Considering that impaired AP repolarization and enhanced repetitive firing of AP were observed in cortical pyramidal neurons of $\mathrm{Na}_{\mathrm{v}} 1 \beta$-null mice [41], we speculate that a decrease in $S C N 1 B$ expression and depletion of $\mathrm{Na}_{\mathrm{v}} 1 \beta$ subunits could contribute to the APV-induced increase in firing rates by down-regulating $\mathrm{K}_{\mathrm{v}} 4.2$ channels.

Consistent with our microarray, the QPCR analysis revealed that $48 \mathrm{~h} \mathrm{BC}$ treatment up-regulated GRIA4, GRM8, and LIN7A whereas $48 \mathrm{~h}$ TTX treatment significantly induced GRM1 and NOS1 and repressed 12 genes involved in synaptic transmission including $A R C$, GRIA4, GRM8, HOMER1, LGI2, LIN7A, RASGRF1, SNCB, BDNF, CAMK4, $G A B R D$, and $C R H$ (Figure 3D). In contrast, only half of the genes involved in synaptic transmission selected for further verification were regulated similarly by APV and TTX (Figure 3D). These genes include ARC, GRIA4, GRM8, RASGRF1, SNCB, BDNF, GABRD, and CRH (Figure 3D). In cortical cultures, exogenous BDNF prevents the TTXinduced increase in AP firing rates, while scavenging endogenous BDNF mimics the increase in intrinsic excitability that occurs with chronic activity blockade [3,31]. Given that BDNF is released in an activity-dependent manner [42] and known to stimulate transcription [43,44], our results in hippocampal neurons is consistent with the hypothesis that BDNF serves as an upstream regulator of homeostatic intrinsic plasticity [1]. Furthermore, RasGRF1 knockout neurons display enhanced spontaneous neuronal activity and AP firing rates in hippocampal neurons [45], suggesting that a decrease in RASGRF1 expression, which occurs with TTX (Figure 3D), may play a role in the homeostatic increase in intrinsic excitability.

\section{Chronic inhibition of L-type VGCCs does not affect intrinsic excitability or expression of most $\mathrm{K}^{+}$channel genes}

Chronic blockade of either L-type VGCCs or the downstream target $\mathrm{Ca}^{2+} /$ calmodulin-dependent protein kinase kinase (CaMKK) mimics TTX-induced synaptic scaling [14]. To investigate whether similar manipulations dictate AP firing frequency, we administered the L-type VGCC antagonist nifedipine (Nif, $20 \mu \mathrm{M}$ ), CaMKK inhibitor STO-
$609(2 \mu \mathrm{M})$, or vehicle control (CTL-DMSO, 0.1\% DMSO) for $48 \mathrm{~h}$. Consistent with previous reports in low-density hippocampal neuronal culture [2], $48 \mathrm{~h}$ treatment with Nif or STO-609 did not alter AP firing frequency of hippocampal neurons cultured at high density for all current injections compared to CTL-DMSO treatment (100 pA, CTL-DMSO: $27.4 \pm 1.5 \mathrm{~Hz}, 20 \mu \mathrm{M}$ Nif: $27.5 \pm$ 1.2 Hz, STO-609: 27.9 $\pm 1.0 \mathrm{~Hz}$ ) (Figure 4A,B). Passive membrane properties as well as AP properties were unaffected by Nif or STO-609 treatment (Tables 1 and 2).

Importantly, $48 \mathrm{~h}$ inhibition of L-type VGCCs had little or no effect on the expression of the majority of intrinsic excitability genes tested, except for KCNAB3, KCNJ12, $K C N M B 2$, and KCNN1. The mRNA levels of KCNAB3 and $K C N J 12$ were increased while those of $K C N M B 2$ and KCNN1 were reduced (Figure 4C). Similarly, 48 h STO609 treatment did not affect the expression of intrinsic excitability genes. Among synaptic genes, Nif treatment decreased $A R C$ and $B D N F$ transcripts and increased GRM1 and NOS1 transcripts (Figure 4D) in a manner that mimicked the altered gene expression induced by TTX at $48 \mathrm{~h}$ (Figure 3D). However, only ARC mRNA was reduced by STO-609 treatment at $48 \mathrm{~h}$ (Figure 4D). The minimal effect on either AP firing frequency or expression of $\mathrm{K}^{+}$channel genes in response to $48 \mathrm{~h}$ Nif or STO-609 administration suggests that a decrease in L-type VGCC/CaMKK-dependent signaling is likely not the primary mediator of the homeostatic increase in intrinsic excitability induced by chronic activity blockade.

\section{Inhibition of NMDARs or L-type VGCCs during chronic activity blockade increases intrinsic excitability to the same extent as chronic activity blockade alone}

To confirm that down-regulation of NMDAR activity but not L-type VGCC activity mediates the compensatory increase in AP firing rates induced by $48 \mathrm{~h}$ TTX treatment, we co-treated cultured hippocampal neurons for $48 \mathrm{~h}$ with TTX $(0.5 \mu \mathrm{M})$ and APV $(100 \mu \mathrm{M})$. Co-treatment with TTX and APV led to a marked enhancement in AP firing rates compared to CTL treatment for all current injections over $60 \mathrm{pA}\left(100 \mathrm{pA}, \mathrm{CTL}-\mathrm{H}_{2} \mathrm{O}: 26.2 \pm 1.7 \mathrm{~Hz}, \mathrm{TTX}+\right.$ APV: $31.8 \pm 0.5 \mathrm{~Hz}, p<0.05$ ) (Figure $5 \mathrm{~A}, \mathrm{~B}$ ). Importantly, we recorded similar AP firing rate increases in neurons treated for $48 \mathrm{~h}$ with TTX alone (Figure $5 \mathrm{~A}, \mathrm{~B}$ ) or APV alone (Figure 3A,B). At $100 \mathrm{pA}$ current injection, the mean AP firing frequency in neurons co-treated with TTX and APV was indifferent from that in TTX-treated neurons and APV-treated neurons $(p>0.05)$ (Figure $5 C)$, further supporting our finding that decreased NMDAR activity contributes to elevated intrinsic excitability following chronic activity blockade. 


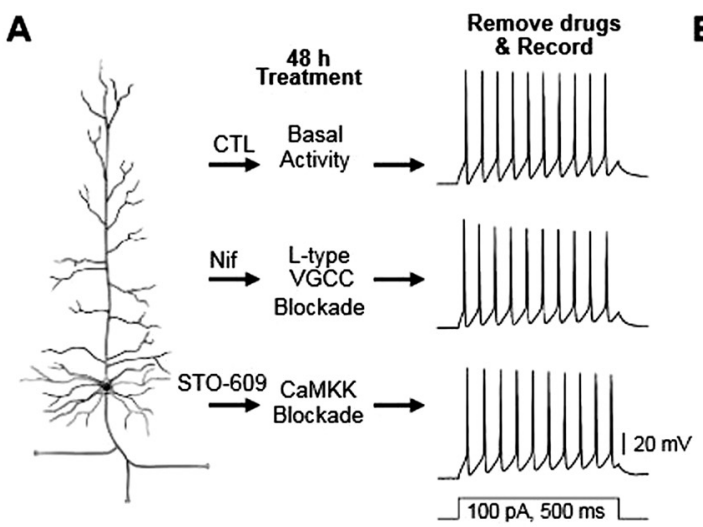

B

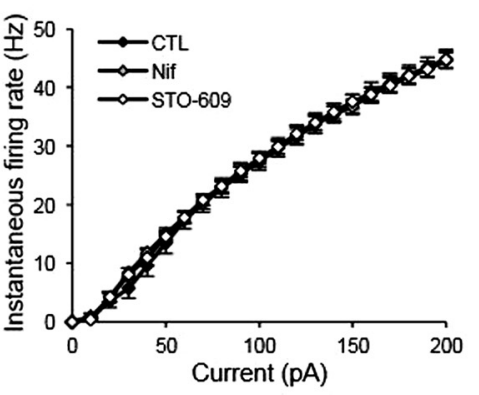

C

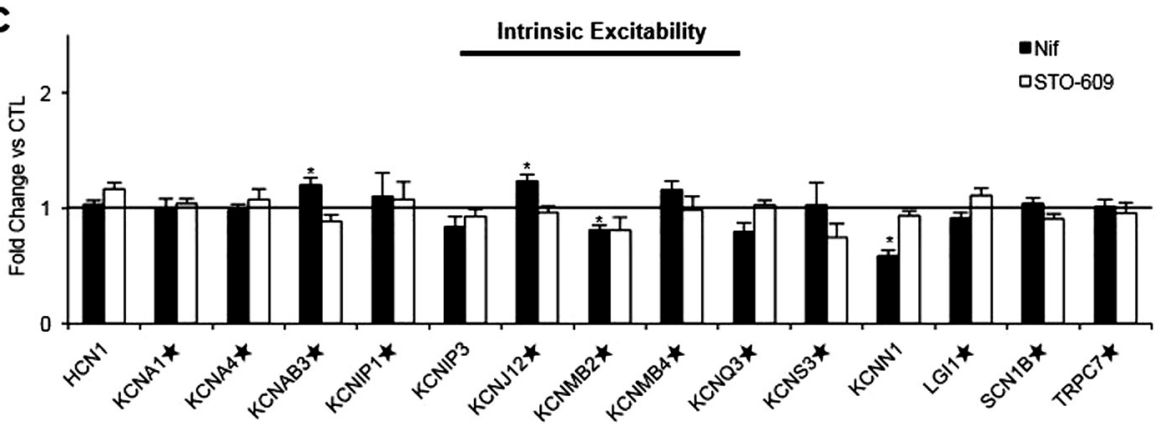

D

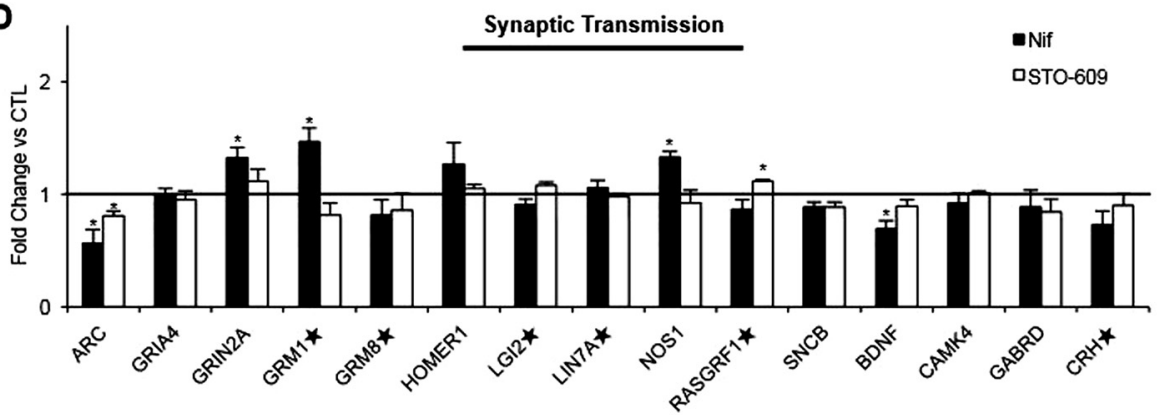

Figure 4 Prolonged inhibition of L-type VGCCs alone does not affect intrinsic excitability or mRNA levels of most $\mathrm{K}^{+}$channel genes. (A,B) Rat dissociated hippocampal neurons cultured at high density (DIV 12-14) were treated with L-type VGCC inhibitor Nif (20 $\mu \mathrm{M})$, CaMKK inhibitor STO-609 (2 $\mu \mathrm{M})$, or control (CTL-DMSO, 0.1\% DMSO) for 48 h. (A) Representative spike trains are shown. (B) Average AP firing rates (Hz) measured in pyramidal neurons treated with CTL-DMSO $(n=12)$, Nif $(n=9)$, or STO-609 $(n=10)$ for 48 h. Nif or STO-609 treatment did not alter AP firing frequency compared to CTL-DMSO treatment. (C,D) QPCR validation of select genes that we identified by microarray analysis and have been implicated in intrinsic excitability (C) and synaptic transmission (D) identified by microarray analysis $(n=5$ per treatment). Expression of intrinsic excitability genes was not altered by Nif or STO-609 treatment, except KCNJ12, KCNMB2, and KCNAB3. The $\star$ denotes genes whose protein products have not previously been implicated in homeostatic plasticity. Mean \pm SEM $\left({ }^{*} p<0.05\right)$.

We demonstrate that $48 \mathrm{~h}$ TTX treatment alone significantly increased AP firing rates (Figure 1, 5A,B, Additional file 3: Figure S2A) whereas Nif treatment alone did not (Figure 4A,B, Additional file 3: Figure S2B). Importantly, co-treatment with TTX and Nif increased the firing rates compared to CTL treatment for all current injections over $70 \mathrm{pA}$ (Figure 5A,B). The mean AP firing frequency in neurons co-treated with TTX and Nif at 100 pA current injection was not different from that in TTX-treated neurons (Figure 5C, TTX + Nif: $31.6 \pm 1.3 \mathrm{~Hz}$; TTX: $32.3 \pm 0.8 \mathrm{~Hz}, p>0.05$ ), which provides evidence that chronic inhibition of L-type VGCC activity alone is not responsible for the homeostatic increase in AP firing rates.

Given that blockade of neuronal activity or inhibition of NMDARs initially decreases $\mathrm{Ca}^{2+}$ influx [14,46-48], our findings suggest that a reduction in intracellular $\mathrm{Ca}^{2+}$ influx through NMDAR but not L-type contributes 


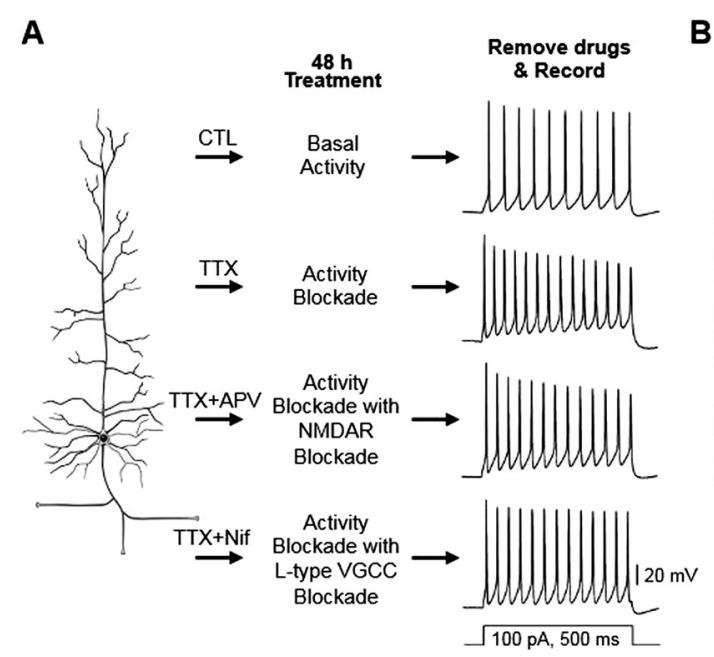

C
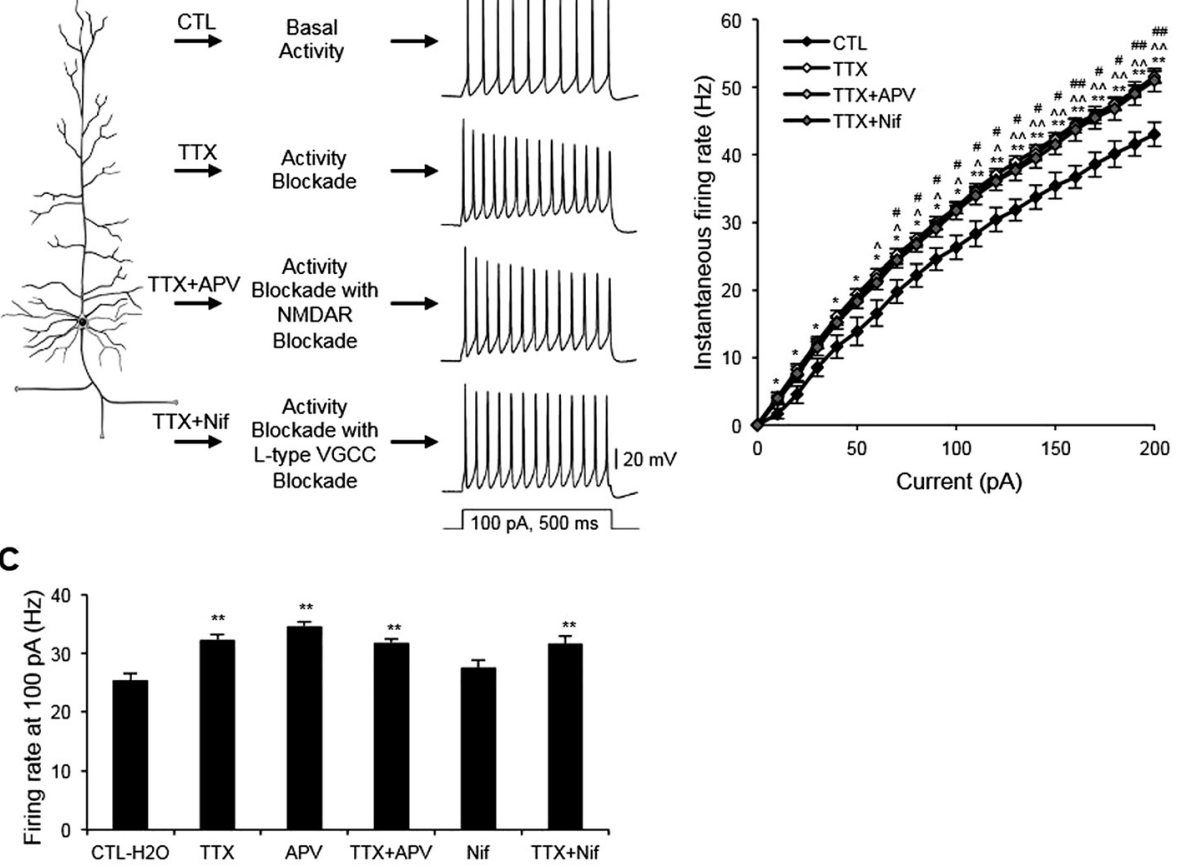

Figure 5 Inhibition of NMDARs or L-type VGCCs during chronic activity blockade increases intrinsic excitability to the same extent as chronic activity blockade alone. (A,B) Rat dissociated hippocampal neurons cultured at high density (DIV 12-14) were treated for $48 \mathrm{~h}$ with control $\left(C \mathrm{CL}-\mathrm{H}_{2} \mathrm{O}, 0.1 \% \mathrm{H}_{2} \mathrm{O}\right)$, TX $(0.5 \mu \mathrm{M})$, TX $(0.5 \mu \mathrm{M})+\mathrm{APV}(100 \mu \mathrm{M})$, or TX $(0.5 \mu \mathrm{M})+\mathrm{Nif}(20 \mu \mathrm{M})$. (A) Representative spike trains are shown. (B) Average AP firing rates $(\mathrm{Hz})$ measured in pyramidal neurons treated for $48 \mathrm{~h}$ with $C \mathrm{CT}-\mathrm{H}_{2} \mathrm{O}(\mathrm{n}=9), \pi \mathrm{T}(\mathrm{n}=10), \pi \mathrm{TX}+\mathrm{APV}(\mathrm{n}=10)$, or $\mathrm{TTX}+\mathrm{Nif}(\mathrm{n}=9)$. Mean \pm SEM $\left({ }^{*} p<0.05,{ }^{* *} p<0.01\right.$ for CTL vs. TTX; $\wedge p<0.05, \wedge \wedge p<0.01$ for CTL vs. TTX + APV; \#p $<0.05$, \#\#p 0.01 for CTL vs. TTX + Nif). (C) A summary plot illustrating the effect of pharmacological treatments on instantaneous firing rates at $100 \mathrm{pA}$. Treatment of hippocampal neurons with TTX and co-treatment with either TTX and APV or TTX and Nif significantly increased AP firing frequency compared to $C T L-H_{2} \mathrm{O}$ treatment. The average AP rates at $100 \mathrm{pA}$ injection for APV and Nif treatments are from Figures $3 \mathrm{~B}$ and $4 \mathrm{~B}$. Mean \pm SEM $\left({ }^{* *} p<0.01\right)$.

to increased intrinsic excitability following chronic activity blockade. This hypothesis is further supported by the fact that only half of the genes involved in synaptic transmission, including GRM1, HOMER1, and CAMK4 (Figure 3D), were down-regulated by TTX treatment but not APV treatment, although both treatments increased AP firing rates (Figures 1, 3A,B, and 5). These results suggest that the increase in intrinsic excitability induced by chronic TTX treatment is not dependent on group I mGluRHomer1a signaling and CaMK4 signaling, despite the crucial roles for these signaling pathways in synaptic scaling $[14,34]$. In addition, $48 \mathrm{~h}$ TTX or Nif treatment but not APV treatment significantly increased the mRNA levels of NOS1 (Figures 3D, 4D), a known regulator of hippocampal long-term potentiation [20]. Considering that prolonged inhibition of L-type VGCC mimics TTX-induced scaling of excitatory synapses [14] and not AP firing rates (Figures $4 \mathrm{~A}, \mathrm{~B}$, and 5 ), our results suggest that enhanced NOS1 expression and NO signaling may play a role in synaptic scaling, but it is unlikely to increase intrinsic excitability upon chronic activity blockade.
Although these results are consistent with previous studies reporting that NMDAR activity does not mediate homeostatic synaptic plasticity in cortical neurons $[13,14,49-51]$, inhibition of NMDAR-mediated $\mathrm{Ca}^{2+}$ influx was recently implicated in synaptic scaling [46]. Kim and Ziff showed that TTX application acutely decreases intracellular $\mathrm{Ca}^{2+}$ concentration in cultured cortical neurons, which was restored by $48 \mathrm{~h}$ via upregulation of synaptic $\mathrm{Ca}^{2+}$-permeable AMPARs [46]. Since APV treatment also causes an initial decline of somatic $\mathrm{Ca}^{2+}$ concentration, the authors suggested that the restoration of $\mathrm{Ca}^{2+}$ levels was initiated by reduced NMDAR activity upon TTX treatment [46]. Consistent with the importance of restoring $\mathrm{Ca}^{2+}$ signaling in homeostatic plasticity, we discovered that $48 \mathrm{~h}$ TTX treatment leads to significant changes in transcripts implicated in "cytosolic $\mathrm{Ca}^{2+}$ ion homeostasis" (Table 3). Thus, additional studies are needed to identify the activity sensor and dissect the underlying signaling pathways responsible for synaptic scaling induced by chronic activity blockade in hippocampal neurons. 
Chronic activity blockade or chronic NMDAR inhibition reduces total $\mathrm{K}^{+}$current, $\mathrm{K}_{\mathrm{v}} 1$ current and $\mathrm{K}_{\mathrm{v}} 7$ current Our microarray analysis and QPCR verification revealed that $48 \mathrm{~h}$ treatment with TTX or APV significantly decreased the mRNA levels of $\mathrm{K}_{\mathrm{v}} 1$ and $\mathrm{K}_{\mathrm{v}} 7$ channels (Figures $2 \mathrm{C}$ and $3 \mathrm{C}$ ) that are critical mediators of excitability in hippocampal neurons [52-57]. To test if the reduction in the $\mathrm{K}^{+}$conductance mediated by these channels may contribute to homeostatic intrinsic plasticity, we first performed immunoblot analyses to examine the changes in $\mathrm{K}_{\mathrm{v}} 1$ and $\mathrm{K}_{\mathrm{v}} 7$ expression. TTX treatment reduced whereas BC application enhanced expression of $\mathrm{K}_{\mathrm{v}} 1.1$, $\mathrm{K}_{\mathrm{v}} 1.4$, and Lgi1 (Figure 6A), the protein products of KCNA1, KCNA4 and Lgi1 (Figure 3C). NMDAR inhibition also decreased $\mathrm{K}_{\mathrm{v}} 1.1$ expression $(p<0.05)$ (Figure 6A).

$\mathrm{K}_{\mathrm{v}} 1$ current critically regulates AP repolarization and wave form-modulation [53,57-60]. Specifically, $\mathrm{K}_{\mathrm{v}} 1.1$ and $\mathrm{K}_{\mathrm{v}} 1.4$ are found predominantly located to axons and generate fast activating and inactivating A-type $\mathrm{K}^{+}$current and fast activating and slowly inactivating $\mathrm{D}$-type $\mathrm{K}^{+}$ current $[9,58,61]$. The epilepsy-associated secreted protein Lgi1 selectively prevents $\mathrm{K}_{\mathrm{v}} 1$ channel inactivation mediated by $\mathrm{K}_{\mathrm{v}} \beta 1$ [62-64]. A-type and D-type $\mathrm{K}^{+}$currents have been shown to decrease rapidly in response to acute activity enhancement. For example, induction of chemical long-term potentiation in hippocampal neuronal culture reduces the A-type $\mathrm{K}^{+}$current [65]. Similarly, a conditional AP train at $10 \mathrm{~Hz}$ for $2 \mathrm{~s}$ was shown to accompany an immediate reduction in the D-type $\mathrm{K}^{+}$current in hippocampal CA3 neurons [66].

To assess whether decreased expression of $\mathrm{K}_{\mathrm{v}} 1.1, \mathrm{~K}_{\mathrm{v}} 1.4$, and Lgi1, which occurs upon chronic activity blockade (Figure 6A), affects $\mathrm{K}_{\mathrm{v}} 1$ current, voltage-clamp recordings were performed to isolate $\mathrm{K}_{\mathrm{v}} 1$ currents using $\mathrm{K}_{\mathrm{v}} 1$ channel specific inhibitor, dendrotoxin-K (DTX-K) (Figure 6B,D,E). In hippocampal neurons cultured at high density, the DTX-K-sensitive $\mathrm{K}_{\mathrm{v}} 1$ currents were significantly decreased upon $48 \mathrm{~h}$ application of TTX $(+40 \mathrm{mV}, 0.41 \pm 0.03 \mathrm{nA}$, $p<0.01)$ or APV $(+40 \mathrm{mV}, 0.50 \pm 0.04 \mathrm{nA}, p<0.05)$ compared to CTL- $\mathrm{H}_{2} \mathrm{O}$ treatment $(+40 \mathrm{mV}, 0.74 \pm 0.09 \mathrm{nA}$,

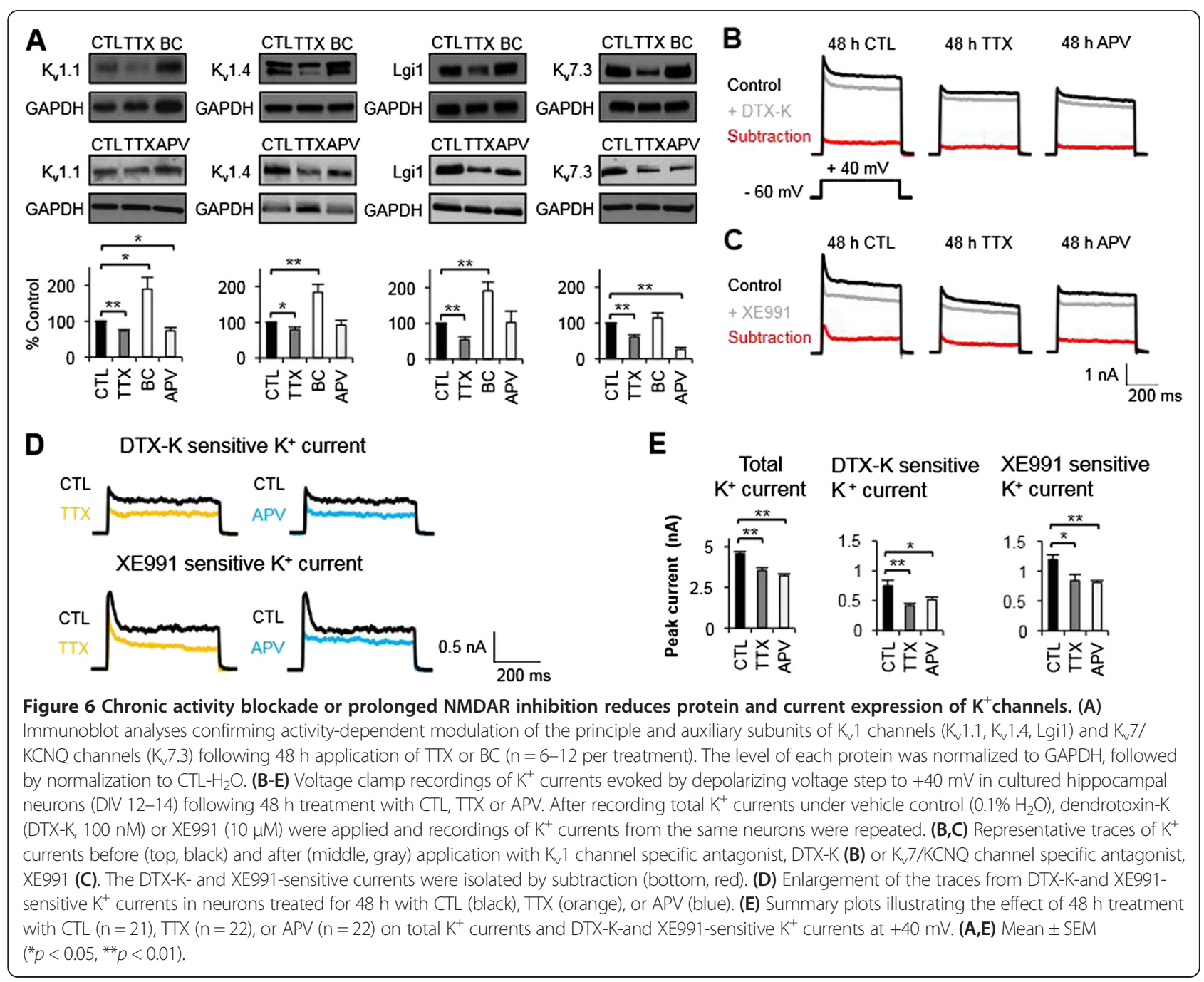


$p<0.01$ ) (Figure 6B,D,E). Whereas down-regulation of Dtype $\mathrm{K}^{+}$current via $\mathrm{K}_{\mathrm{v}} 1.2$ internalization was observed upon acute enhancement of somatic activity in hippocampal CA3 neurons to mediate long-term potentiation of intrinsic excitability [66], our findings suggest that a decrease in $\mathrm{K}_{\mathrm{v}} 1$ current could contribute to a homeostatic increase of AP firing frequency in response to chronic activity blockade or prolonged inhibition of NMDARs.

TTX or APV treatment also reduced expression of $\mathrm{K}_{\mathrm{v}} 7.3$ $(p<0.05)$ (Figure 6A), the subunit encoded by KCNQ3 (Figure 3C). Although neurons express $\mathrm{K}_{\mathrm{v}} 7.2-\mathrm{K}_{\mathrm{v}} 7.5$ [67], $\mathrm{K}_{\mathrm{v}} 7$ channels composed of $\mathrm{K}_{\mathrm{v}} 7.2$ and $\mathrm{K}_{\mathrm{v}} 7.3$ produce slowly activating and non-inactivating $\mathrm{M}$-type $\mathrm{K}^{+}$current, which potently suppresses repetitive AP firing $[52,55,56,68]$. To test if TTX or APV treatment for $48 \mathrm{~h}$ decreases $\mathrm{K}_{\mathrm{v}} 7$ current, voltage-clamp recordings were repeated to isolate $\mathrm{K}_{\mathrm{v}} 7$ currents using $\mathrm{K}_{\mathrm{v}} 7 / \mathrm{KCNQ}$ channel specific antagonist, XE991 (Figure 6C-E). TTX or APV treatment significantly reduced the XE991-sensitive $\mathrm{K}_{\mathrm{v}} 7$ currents $(+40 \mathrm{mV}$, TTX: $0.83 \pm 0.09 \mathrm{nA}$, APV: $0.80 \pm 0.03 \mathrm{nA}$ ) compared to CTL- $\mathrm{H}_{2} \mathrm{O}$ treatment $(+40 \mathrm{mV}, 1.18 \pm 0.08 \mathrm{nA}, p<0.05)$ (Figure 6C-E). Sustained excitation has been shown to potentiate hippocampal $K_{\mathrm{v}} 7$ function and spike frequency adaptation [69]. Conversely, our results suggest that reduction in $\mathrm{K}_{\mathrm{v}} 7$ current and $\mathrm{K}_{\mathrm{v}} 7.3$ (Figure 6), which is the dominant subunit that targets KCNQ channel to the axonal initial segment [70-72], may contribute to homeostatic stabilization of AP firing in response to chronic activity blockade or prolonged inhibition of NMDARs. Interestingly, XE991-sensitive current in APV-treated neurons became non-inactivating compared to that of TTX-treated neurons (Figure 6D). Though highly speculative, this could be due to the possibility that APV treatment may down-regulate $\mathrm{K}_{\mathrm{v}} 7.4$ and/ or $\mathrm{K}_{\mathrm{v}} 7.5$ subunits that mediate inactivation [73].

Furthermore, TTX or APV treatment also reduced total $\mathrm{K}^{+}$current (Figure 6B,C,E), which is consistent with our results that these treatments down-regulate multiple $\mathrm{K}^{+}$ channel transcripts (Figures $2 \mathrm{C}$ and $3 \mathrm{C}$ ). For example, TTX or APV treatment decreased HCN1 and KCNMB2 mRNAs, which encode $\mathrm{HCN}$ channels and $\mathrm{BK} \beta 2$, respectively. Enriched dendritically, $\mathrm{HCN}$ channels mediate activity-dependent h-current $\left(I_{\mathrm{h}}\right)$ [74-76], which attenuates summation of excitatory postsynaptic potentials $[77,78]$. Thus, a decrease in HCN1 expression, which occurs with TTX (Figures 2C and 3C), could enhance dendritic excitability. In hippocampal neurons, inactivation of BK channels contributes to frequency-dependent spike broadening [79]. Given that BK $\beta 2$ promotes inactivation of BK channels [80], a reduction in $B K \beta 2$ could potentiate intrinsic excitability by regulating AP repolarization and spike afterhyperpolarization $[53,81,82]$. Reduction in total $\mathrm{K}^{+}$current by $48 \mathrm{~h}$ TTX or APV treatment (Figure $6 \mathrm{~B}, \mathrm{C}, \mathrm{E}$ ) is also consistent with our findings that these treatments significantly increase the input resistance of hippocampal neurons without altering their resting membrane potential (Table 1 ). These changes are most likely caused by the closure of ion channels, especially $\mathrm{K}^{+}$channels. These results together suggest that a homeostatic increase in AP firing upon prolonged activity blockade may be achieved, in part, by NMDAR-dependent down-regulation of multiple $\mathrm{K}^{+}$channels including $\mathrm{K}_{\mathrm{v}} 1$ and $\mathrm{K}_{\mathrm{v}} 7$ channels.

\section{Homeostatic intrinsic plasticity in high-density versus low-density hippocampal neuronal culture}

We have previously reported that $\mathrm{BC}$ treatment for $48 \mathrm{~h}$ leads to a reduction in AP firing rates compared to CTL treatment in dissociated hippocampal neurons cultured at low density [2]. However, we did not observe the same effect in age-matched, high-density cultures (Figure 1). Since hippocampal neurons in high-density cultures are more excitable than those in low-density cultures (Additional file 4: Figure S3, Additional files 5 and 6: Tables S2 and S3), we speculate that inhibition of GABAergic transmission in hippocampal neurons cultured at high density may be insufficient to increase network activity required for the induction of homeostatic intrinsic plasticity.

Although TTX treatment for $48 \mathrm{~h}$ caused a homeostatic increase in AP firing rates in both high- and lowdensity cultures (Figure 1) [2], the same treatment reduced total $\mathrm{K}^{+}$current in hippocampal neurons cultured at high density (Figure 6) but not those in lowdensity culture [2]. This could be due to the fact that CTL-treated, high-density cultures displayed larger total $\mathrm{K}^{+}$current (Figure 6) than low-density cultures [2], enabling us to detect its significant reduction upon TTX treatment. Although we cannot exclude the possibility that ionic conductance mediating TTX-induced homeostatic intrinsic plasticity may not be equivalent in both high- and low-density cultures, our findings (Figure 6) are consistent with previous studies reporting that the elevation in AP firing frequency, which occurs with TTX treatment, is coupled with reduced $\mathrm{K}^{+}$current density in dissociated cortical neurons [4].

Despite the wide application of dissociated neuronal culture to study homeostatic plasticity $[2-4,13,15,29-31$, 34,83 , the results from this culture system should be interpreted with caution due to the dependence of homeostatic plasticity expression on culture density and age $[28,84]$. Remarkably, TTX and APV treatments but not Nif or STO-609 treatments led to a homeostatic increase in AP firing rates in both high-density (Figures 1, 3 and 4) and low-density cultures [2]. Importantly, co-treatment of neurons with either TTX and APV or TTX and Nif did not increase AP firing frequency to a greater extent than TTX treatment alone (Figure 5). Thus, regardless of culture density, homeostatic intrinsic plasticity induced by 
chronic activity blockade is most likely mediated by reduced activity of NMDARs and not L-type VGCCs (Figure 7).

\section{Conclusions}

We have identified a novel NMDAR-mediated $\mathrm{K}^{+}$channelrich gene network dynamically regulated during homeostatic intrinsic plasticity in hippocampal neurons cultured at high density. Our findings support a critical role for the transcriptional down-regulation of a variety of $\mathrm{K}^{+}$channels in the stabilization of hippocampal neuronal excitability upon chronic activity blockade (Figure 7). In contrast to a homeostatic increase in synaptic strength mediated by reduced activity of L-type VGCCs during chronic activity blockade [14], our findings indicate that the level of $\mathrm{Ca}^{2+}$ influx through NMDARs serves as a critical activity sensor capable of initiating transcriptional regulation of genes crucial for homeostatic intrinsic plasticity (Figure 7). We propose that homeostatic intrinsic plasticity induced by chronic activity blockade is achieved in 3 steps: (1) inhibition of neuronal activity initially decreases $\mathrm{Ca}^{2+}$ influx through NMDARs [14,46-48]; (2) transcriptional downregulation of multiple $\mathrm{K}^{+}$channel genes decreases expression of $\mathrm{K}^{+}$channels; and (3) reduced current through these $\mathrm{K}^{+}$channels regulates AP and passive properties of hippocampal neurons to increase AP firing rates. In addition to $\mathrm{K}^{+}$channels, this study reveals a number of previously unknown targets of homeostatic plasticity, including genes that have been implicated in the regulation of synaptic strength by influencing release probability and postsynaptic receptor function [19-25,29-34] as well as maintaining $\mathrm{Ca}^{2+}$ homeostasis [46]. Future studies should explore how activity-dependent genes work together to simultaneously induce synaptic scaling and homeostatic intrinsic plasticity. Given that homeostatic intrinsic plasticity is hypothesized to contribute to hyperexcitabilityassociated neuropathologies $[16,18,85]$, deciphering the activity-dependent transcriptional regulation of $\mathrm{K}^{+}$channels during homeostatic intrinsic plasticity may also reveal novel therapeutic targets for these diseases.

\section{Materials and methods \\ Materials}

Chemical reagents used included tetrodotoxin, bicuculline, DL-2-amino-5-phosphonopentanoic, Nifedipine, STO-609 acetate, XE991 dihydrochloride (all Tocris), and dendrotoxin-K (Alomone). Antibodies used included anti-Lgi1 (Abcam), anti-GAPDH (Cell Signaling), anti$\mathrm{K}_{\mathrm{v}} 1.1$ (Millipore), anti- $\mathrm{K}_{\mathrm{v}} 1.1$, anti- $\mathrm{K}_{\mathrm{v}} 1.4$ (Neuromab), and anti-KCNQ3 (Alamone, or a kind gift from Dr. E. Cooper, Baylor College of Medicine, Houston, Texas).

\section{Hippocampal neuronal culture}

All experimental procedures involving animals were approved by the Institutional Animal Care and Use Committee at the University of California San Francisco and the University of Illinois Urbana-Champaign. Primary dissociated hippocampal cultures were prepared from E18.5 Sprague-Dawley rat embryos as described [2] and plated at high density $\left(330\right.$ cells $/ \mathrm{mm}^{2}$ ) onto poly L-lysine-coated $(0.1 \mathrm{mg} / \mathrm{mL}) 12 \mathrm{~mm}$ glass coverslips $\left(1.5 \times 10^{5}\right.$ cells/ coverslip), or 30 or $60 \mathrm{~mm}$ cell culture dishes $\left(6.5 \times 10^{5}\right.$

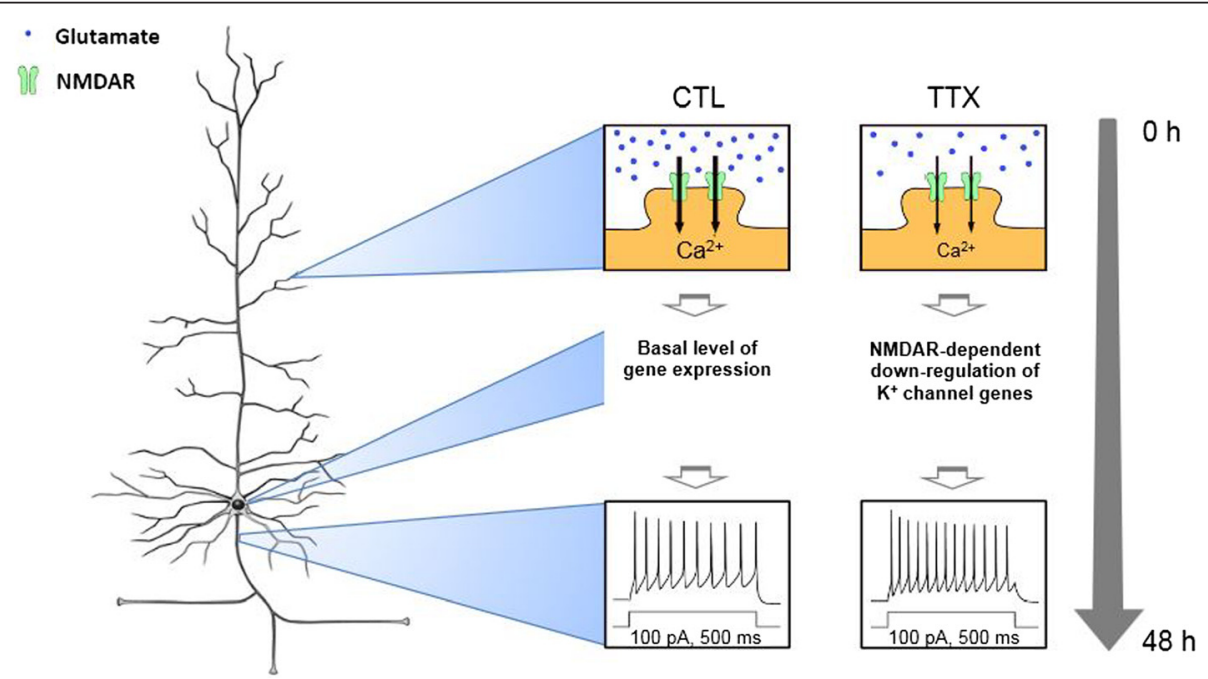

Figure $\mathbf{7}$ Model for $\mathrm{K}^{+}$channel regulation during induction of homeostatic intrinsic plasticity. $\Pi \mathrm{TX}$ application rapidly blocks spontaneous action potential firing, causing an initial decrease in $\mathrm{Ca}^{2+}$ influx through NMDARs in dissociated hippocampal neurons cultured at high density. The subsequent transcriptional down-regulation of multiple $\mathrm{K}^{+}$channel genes leads to a reduction in the protein expression of $\mathrm{K}^{+}$channels at the neuronal plasma membrane. By $48 \mathrm{~h}$, a decrease in currents through these $\mathrm{K}^{+}$channels regulates AP and passive properties of hippocampal neurons, resulting in a homeostatic increase in the AP firing rates. The representative AP traces in the insets are from Figure $1 \mathrm{~A}$. 
or $2.3 \times 10^{6}$ cells/dish, respectively). At 10-13 days in vitro (DIV), neurons were treated for $48 \mathrm{~h}$ with $\left(\mathrm{CTL}-\mathrm{H}_{2} \mathrm{O}\right.$, 0.1\% $\left.\mathrm{H}_{2} \mathrm{O}\right)$, (CTL-DMSO, 0.1\% DMSO), TTX (0.5-1 $\left.\mu \mathrm{M}\right)$, BC $(20 \mu \mathrm{M})$, APV $(100-200 \mu \mathrm{M})$, Nif $(20 \mu \mathrm{M})$, or STO$609(2 \mu \mathrm{M})$.

\section{RNA isolation and microarray analysis}

Following pharmacological treatment, total RNA was isolated using an RNeasy kit (Qiagen) and stored at $-80^{\circ} \mathrm{C}$. Total RNA quality and quantity was assessed using a Pico Chip on an Agilent 2100 Bioanalyzer and Nanodrop ND-100 spectrophotometer. Quadruplicate RNA samples for each treatment were submitted to the UCSF Sandler Center Functional Genomics Core Facility for cDNA microarray hybridization to whole rat genome $4 \times 44 \mathrm{~K}$ Ink-jet arrays (Agilent, 41,012 total gene probes). Subsequent data extraction and analysis were performed at the core facility to determine the quantile normalization [86], B statistic [87], false discovery rate (FDR) [88] using the $\mathrm{R}$ package limma in Bioconductor $[89,90]$. Gene probes with an FDR $<0.05$ and fold change of $\leq 0.667$ (repressed) or $\geq 1.5$ (induced) were considered differentially regulated. Gene ontology was analyzed using DAVID bioinformatics resources (http://david.abcc.ncifcrf.gov) [91] and primary literature searches.

\section{QPCR}

To synthesize cDNA, reverse transcription was performed using total RNA $(1-2 \mu \mathrm{g})$, random nanomers $(15 \mu \mathrm{M})$, dNTPs $(25 \mathrm{mM}), \mathrm{M}-\mathrm{MuLV}$ reverse transcriptase $(200 \mathrm{U} / \mu \mathrm{L})$, and RNase inhibitor $(40 \mathrm{U} / \mu \mathrm{L})(\mathrm{New}$ England Biolabs). The resulting cDNA was subjected to QPCR using the StepOnePlus real-time PCR system (Applied Biosystems) and SYBRGreenI (Invitrogen) to enable real-time quantification as described [92] with primers homologous to cDNAs corresponding to 31 genes of interest and GAPDH control gene (Additional file 7: Table S4). Primer efficiency was within 90-110\% on a standard curve (slope of $-3.30=100 \%$ optimal efficiency), with an $\mathrm{R}^{2}$ correlation coefficients $>0.99$, and threshold cycle $(\mathrm{Ct})$ values $>8$ and $<35$. The QPCR product specificity was confirmed through melt curve analysis. Following normalization to GAPDH cDNA levels, which is reflected in the $\Delta \mathrm{Ct}$ values, the relative quantification (RQ) of the fold change for each treatment compared to reference control was determined using the following equations: $R Q=2^{(-\Delta C t)} / 2^{(-\Delta C t \text { reference })}$.

\section{Immunoblot analysis}

Following pharmacological treatment, hippocampal cultured neurons were lysed in RIPA buffer and the resulting lysate samples were subjected to immunoblot analysis as described [93]. Densitometric quantification, following normalization to GAPDH was performed with Image software (National Institutes of Health) as described [93].

\section{Whole cell patch clamp recordings}

Whole-cell patch clamp recordings of AP firing and $\mathrm{K}^{+}$ currents were carried out at $23-25^{\circ} \mathrm{C}$ in neurons held at $-60 \mathrm{mV}$ as previously described [2] using a Multiclamp 700B amplifier, Digidata 1440A, and the pClamp 10.2 (Molecular Devices). Recordings were filtered at $2 \mathrm{kHz}$ and digitized at $10 \mathrm{kHz}$. Recording analyses were performed using Clampfit 10.2 (Molecular Devices). Current clamp recordings of spontaneous AP firing were carried out as previously described [2] immediately after applying vehicle control $(0.1 \% \mathrm{dH} 2 \mathrm{O})$, TTX $(0.5-1 \mu \mathrm{M})$, or $\mathrm{BC}(20 \mu \mathrm{M})$ in external solution containing (in $\mathrm{mM}$ ): 126 $\mathrm{NaCl}, 3 \mathrm{KCl}, 2 \mathrm{CaCl}_{2}, 2 \mathrm{MgSO}_{4}, 1 \mathrm{NaH}_{2} \mathrm{PO}_{4}, 25 \mathrm{NaHCO}_{3}$ and 14 Dextrose, bubbled with $95 \% \mathrm{O}_{2}$ and $5 \% \mathrm{CO}_{2}$ ( $\mathrm{pH} 7.4,305-315 \mathrm{mOsm}$ ). Recording pipettes had a resistance of 3-5 M $\Omega$ when filled with internal solution containing (in $\mathrm{mM}$ ): $130 \mathrm{KMeSO}_{4}, 10 \mathrm{KCl}, 10 \mathrm{HEPES} / \mathrm{K}-\mathrm{HEPES}, 2$ $\mathrm{MgSO}_{4}, 0.5$ EGTA and 3 ATP (pH 7.3, 285-295 mOsm). Spontaneous firing was measured upon delivering zero current $(0 \mathrm{pA})$ pulses.

To examine the induction of homeostatic intrinsic plasticity, current clamp recordings of AP were carried out immediately after the removal of $48 \mathrm{~h}$ TTX or BC treatment in external solution in the presence of the fast synaptic transmission blockers CNQX $(20 \mu \mathrm{M})$ and APV $(100 \mu \mathrm{M})$. AP firing rates $(\mathrm{Hz})$ were measured upon delivering constant current pulses of $500 \mathrm{~ms}$ in the range 0 to $200 \mathrm{pA}$, and were averaged from 3 to 5 individual sweeps per each current injection. Neurons were omitted if the resting membrane potential was $>-50 \mathrm{mV}$, or if no APs were discharged. Rheobase was defined as the minimal current that elicited at least one spike by incremental 10 pA current steps for $500 \mathrm{~ms}$ duration at a holding potential of $-60 \mathrm{mV}$ [39].

Voltage-clamp recordings of $\mathrm{K}^{+}$currents were performed in external solution containing CNQX $(20 \mu \mathrm{M})$ and APV $(100 \mu \mathrm{M})$ to block the fast synaptic transmission as well as TTX $(0.5 \mu \mathrm{M})$ and $\mathrm{CdCl}_{2}(400 \mu \mathrm{M})$ to block the $\mathrm{Na}^{+}$and $\mathrm{Ca}^{2+}$ currents, respectively. Depolarizing steps (500 ms) were applied every $10 \mathrm{~s}$ intervals in $+10 \mathrm{mV}$ increments up to $+40 \mathrm{mV}$. After recording $\mathrm{K}^{+}$currents under vehicle control $\left(0.1 \% \mathrm{H}_{2} \mathrm{O}\right)$, the neurons were exposed to XE991 $(10 \mu \mathrm{M})$ or dendrotoxin-K (DTX-K, 100 $\mathrm{nM}$ ) and recordings of $\mathrm{K}^{+}$currents were repeated. The XE991-sensitive $\mathrm{K}_{\mathrm{v}} 7$ currents or DTX-K-sensitive $\mathrm{K}_{\mathrm{v}} 1$ currents were computed by subtracting the $\mathrm{K}^{+}$currents recorded in the presence of the inhibitors from the $\mathrm{K}^{+}$currents recorded under the control condition.

\section{Statistical analyses}

All data shown represent the mean value \pm SEM. The number of separate neuronal culture dishes, RNA samples, 
and cells patched for electrophysiological studies are expressed as sample size $n$. Statistical analyses were performed with Microsoft Excel and Origin 9.1 (Origin Lab). Following Student's t test or ANOVA, a priori value $(p)<0.05$ was considered statistically significant.

\section{Additional files}

Additional file 1: Figure S1. Effects of acute TTX or BC treatment on spontaneous firing of hippocampal pyramidal neurons. (A) Whole-cell patch clamp recording of rat dissociated hippocampal neurons cultured at high density (DIV 12-14) revealed that acute application of TTX $(0.5 \mu \mathrm{M})$ rapidly blocks spontaneous firing of AP whereas acute application of BC (20 $\mu \mathrm{M})$ leads to burst firing compared to $\mathrm{CTL}-\mathrm{H}_{2} \mathrm{O}$ treatment.

Additional file 2: Table S1. The average rheobase current of hippocampal pyramidal neurons cultured at high-density following $48 \mathrm{~h}$ pharmacological treatment. Rheobase (the minimal current that elicited at least one spike) was determined by incremental $10 \mathrm{pA}$ current steps for $500 \mathrm{~ms}$ duration at a holding potential of $-60 \mathrm{mV}$. Each value represents the mean \pm SEM $\left(* * p<0.01\right.$ for $C T L-H_{2} \mathrm{O}$ vs. APV).

Additional file 3: Figure S2. The AP firing rates in response to current injections from rheobase to rheobase $+100 \mathrm{pA}$. Average AP firing rates $(\mathrm{Hz})$ shown in Figures 1, 3 and 4 were recalculated in response to current injections from rheobase to rheobase $+100 \mathrm{pA}$. (A) Treatment of hippocampal neurons for $48 \mathrm{~h}$ with TTX $(n=10)$ or APV $(n=9)$ significantly increased AP firing frequency compared to $C T L-H_{2} \mathrm{O}$ treatment $(n=22)$. (B) Treatment for $48 \mathrm{~h}$ with Nif $(n=9)$ or STO-609 $(n=10)$ did not alter AP firing frequency compared to CTL-DMSO treatment $(n=12)$. (C) BC application for $48 \mathrm{~h}$ $(n=9)$ did not change AP firing frequency compared to CTL- $\mathrm{H}_{2} \mathrm{O}$ application $(n=22)$. Mean \pm SEM $\left({ }^{*} p<0.05,{ }^{* *} p<0.01\right.$ for CTL vs. TTX; $\wedge p<0.05, \wedge \wedge p<$ 0.01 for (TL vs. APV).

Additional file 4: Figure S3. Effect of culture density on innate excitability of hippocampal pyramidal neurons. $(A, B)$ Whole-cell patch clamp recording of rat dissociated hippocampal neurons cultured at high density and low density (DIV 12-14) after $48 \mathrm{~h}$ application of vehicle control $\left(\mathrm{CTL}, 0.1 \% \mathrm{H}_{2} \mathrm{O}\right)$. Following treatment removal, spike trains were evoked in pyramidal neurons by delivering constant somatic current pulses for $500 \mathrm{~ms}$ duration at a resting potential of $-60 \mathrm{mV}$. (A) Representative spike trains are shown. (B) Average AP firing rates $(\mathrm{Hz})$ were measured in pyramidal neurons cultured at high density $(\mathrm{n}=22)$ and low density $(n=22)$. Mean \pm SEM $\left({ }^{*} p<0.05\right.$, ${ }^{* *} p<0.01$ for CTL-LD vs. CTL-HD).

Additional file 5: Table S2. Passive properties of hippocampal pyramidal neurons cultured at low density. $n$, number; $\mathrm{Cm}$, Whole-cell membrane capacitance; $R$ in, input resistance; $V \mathrm{~m}$, resting membrane potential. Each value represents the mean \pm SEM.

Additional file 6: Table S3. AP properties of hippocampal pyramidal neurons cultured at low density. $V T$, voltage threshold for action potential; AP, Action potential; rise, 10-90\% rise time of AP; decay, 10-90\% decay time of AP; HW, half-width; fAHP, fast after-hyperpolarization. AP properties were measured from the first action potential evoked by a current step to $100 \mathrm{pA}$ at a holding potential of $-60 \mathrm{mV}$. Each value represents the mean \pm SEM $\left({ }^{*} p<0.05\right.$ for CTL-LD vs. CTL-HD).

Additional file 7: Table S4. Primer pairs for QPCR analysis. Primers were designed with Primer3 software (Whitehead Institute). Primer efficiency was within $90-110 \%$ on a standard curve (slope of $-3.30=$ $100 \%$ optimal efficiency), with an R2 correlation coefficients $>0.99$, and threshold cycle (CT) values $>8$ and $<35$.

\section{Abbreviations}

AP: Action potential; APV: DL-2-amino-5-phosphonopentanoic acid

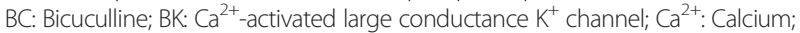
CaMKK: $\mathrm{Ca}^{2+} /$ calmodulin-dependent protein kinase kinase; CTL: Control; DIV: Days in vitro; DTX-K: Dendrotoxin-K; h: Hours; HCN: Hyperpolarization activated cyclic nucleotide-gated $\mathrm{K}^{+}$channel; $\mathrm{K}^{+}$: Potassium; NMDA: N-Methyl-D-aspartate; VGCC: Voltage-gated $\mathrm{Ca}^{2+}$ channel; QPCR: Real-time quantitative polymerase chain reaction; SK: $\mathrm{Ca}^{2+}$-activated small conductance $\mathrm{K}^{+}$channel; THIK2: Tandem pore domain halothane-inhibited $\mathrm{K}^{+}$channel 2; TRAAK: TWIK-related arachidonic acid-stimulated $\mathrm{K}^{+}$channel; TREK1: TWIK-related $\mathrm{K}^{+}$channel 1; TTX: Tetrodotoxin; XE991: XE991 dihydrochloride.

\section{Competing interests}

The authors declare that they have no competing interests.

\section{Authors' contributions}

KYL carried out the electrophysiological recordings and the statistical analysis. HJC, SER, KYL, MOV, and DJL performed analysis on microarray and gene ontology. HJC, SER, KYL, and SL carried out immunoblot analysis. MOV and DJL performed QPCR. HJC conceived of the study and participated in its design and coordination. HJC, SER, and KYL drafted the manuscript. ECB provided critical reagents and equipment for QPCR analysis and edited the manuscript. All authors read and approved the final manuscript.

\section{Acknowledgements}

This work is supported by Roy J. Carver Charitable Trust New Investigator Grant 11-3887 (HJC) and ICR Start-up fund from the University of Illinois at Urbana Champaign (HJC). We thank Dr. Lily Y. Jan (University of California, San Francisco) for providing reagents for microarray analysis and insightful comments on the manuscript. We thank Dr. Edward C. Cooper (Baylor College of Medicine) for providing antibodies for KCNQ3. We thank John P. Cavaretta for his technical assistance with neuronal culture and editing the manuscript.

\section{Author details}

'Department of Molecular and Integrative Physiology, University of Illinois at Urbana-Champaign, 407 South Goodwin Avenue, 524 Burrill Hall, Urbana, IL 61801 , USA. ${ }^{2}$ Program in Neuroscience Program, University of Illinois at Urbana-Champaign, Urbana, Illinois 61801, USA. ${ }^{3}$ Medical Scholars Program, University of Illinois at Urbana-Champaign, Urbana, Illinois 61801, USA.

Received: 18 September 2014 Accepted: 7 January 2015

Published online: 20 January 2015

\section{References}

1. Watt AJ, Desai NS. Homeostatic plasticity and STDP: keeping a Neuron's cool in a fluctuating world. Front Synaptic Neurosci. 2010;2:5.

2. Lee KY, Chung HJ. NMDA receptors and L-type voltage-gated Ca2+ channels mediate the expression of bidirectional homeostatic intrinsic plasticity in cultured hippocampal neurons. Neuroscience. 2014;277:610-23.

3. Desai NS, Rutherford LC, Turrigiano GG. BDNF regulates the intrinsic excitability of cortical neurons. Learn Mem. 1999;6:284-91.

4. Desai NS, Rutherford LC, Turrigiano GG. Plasticity in the intrinsic excitability of cortical pyramidal neurons. Nat Neurosci. 1999;2:515-20.

5. Karmarkar UR, Buonomano DV. Different forms of homeostatic plasticity are engaged with distinct temporal profiles. Eur J Neurosci. 2006:23:1575-84.

6. Sokolova IV, Mody I. Silencing-induced metaplasticity in hippocampal cultured neurons. J Neurophysiol. 2008;100:690-7.

7. Echegoyen J, Neu A, Graber KD, Soltesz I. Homeostatic plasticity studied using in vivo hippocampal activity-blockade: synaptic scaling, intrinsic plasticity and age-dependence. PLoS One. 2007;2:e700.

8. Seeburg DP, Sheng M. Activity-induced Polo-like kinase 2 is required for homeostatic plasticity of hippocampal neurons during epileptiform activity. J Neurosci. 2008;28:6583-91.

9. Vacher H, Mohapatra DP, Trimmer JS. Localization and targeting of voltagedependent ion channels in mammalian central neurons. Physiol Rev. 2008:88:1407-47.

10. O'Leary T, Williams AH, Caplan JS, Marder E. Correlations in ion channel expression emerge from homeostatic tuning rules. Proc Natl Acad Sci U S A. 2013;110:E2645-54.

11. Goold CP, Nicoll RA. Single-cell optogenetic excitation drives homeostatic synaptic depression. Neuron. 2010;68:512-28.

12. van Welie I, van Hooft JA, Wadman WJ. Homeostatic scaling of neuronal excitability by synaptic modulation of somatic hyperpolarization-activated Ih channels. Proc Natl Acad Sci U S A. 2004;101:5123-8.

13. Thiagarajan TC, Lindskog M, Tsien RW. Adaptation to synaptic inactivity in hippocampal neurons. Neuron. 2005;47:725-37. 
14. Ibata K, Sun Q, Turrigiano GG. Rapid synaptic scaling induced by changes in postsynaptic firing. Neuron. 2008;57:819-26.

15. O'Leary T, van Rossum MC, Wyllie DJ. Homeostasis of intrinsic excitability in hippocampal neurones: dynamics and mechanism of the response to chronic depolarization. J Physiol. 2010;588:157-70.

16. O'Leary T, Williams AH, Franci A, Marder E. Cell types, network homeostasis, and pathological compensation from a biologically plausible ion channel expression model. Neuron. 2014;82:809-21.

17. Flavell SW, Greenberg ME. Signaling mechanisms linking neuronal activity to gene expression and plasticity of the nervous system. Annu Rev Neurosci. 2008;31:563-90.

18. Turrigiano G. Too many cooks? Intrinsic and synaptic homeostatic mechanisms in cortical circuit refinement. Annu Rev Neurosci. 2011;34:89-103.

19. Garthwaite J, Boulton CL. Nitric oxide signaling in the central nervous system. Annu Rev Physiol. 1995;57:683-706.

20. Bon CL, Garthwaite J. On the role of nitric oxide in hippocampal long-term potentiation. J Neurosci. 2003;23:1941-8.

21. Erdmann E, Rupprecht V, Matthews E, Kukley M, Schoch S, Dietrich D. Depression of release by mGluR8 alters $\mathrm{Ca} 2+$ dependence of release machinery. Cereb Cortex. 2012;22:1498-509.

22. Butz S, Okamoto M, Sudhof TC. A tripartite protein complex with the potential to couple synaptic vesicle exocytosis to cell adhesion in brain. Cell. 1998;94:773-82.

23. Cabin DE, Shimazu K, Murphy D, Cole NB, Gottschalk W, Mcllwain KL, et al. Synaptic vesicle depletion correlates with attenuated synaptic responses to prolonged repetitive stimulation in mice lacking alpha-synuclein. J Neurosci. 2002;22:8797-807.

24. Liu S, Ninan I, Antonova I, Battaglia F, Trinchese F, Narasanna A, et al. alphaSynuclein produces a long-lasting increase in neurotransmitter release. EMBO J. 2004;23:4506-16.

25. Olsen O, Moore KA, Fukata M, Kazuta T, Trinidad JC, Kauer FW, et al. Neurotransmitter release regulated by a MALS-liprin-alpha presynaptic complex. J Cell Biol. 2005;170:1127-34.

26. Moulder KL, Meeks JP, Shute AA, Hamilton CK, de Erausquin G, Mennerick S. Plastic elimination of functional glutamate release sites by depolarization. Neuron. 2004:42:423-35.

27. Murthy VN, Schikorski T, Stevens CF, Zhu Y. Inactivity produces increases in neurotransmitter release and synapse size. Neuron. 2001;32:673-82.

28. Han EB, Stevens CF. Development regulates a switch between post- and presynaptic strengthening in response to activity deprivation. Proc Natl Acad Sci U S A. 2009;106:10817-22.

29. Shepherd JD, Rumbaugh G, Wu J, Chowdhury S, Plath N, Kuhl D, et al. Arc/ Arg3.1 mediates homeostatic synaptic scaling of AMPA receptors. Neuron. 2006;52:475-84.

30. Rutherford LC, DeWan A, Lauer HM, Turrigiano GG. Brain-derived neurotrophic factor mediates the activity-dependent regulation of inhibition in neocortical cultures. J Neurosci. 1997;17:4527-35.

31. Rutherford LC, Nelson SB, Turrigiano GG. BDNF has opposite effects on the quantal amplitude of pyramidal neuron and interneuron excitatory synapses. Neuron. 1998;21:521-30.

32. Swanwick CC, Murthy NR, Kapur J. Activity-dependent scaling of GABAergic synapse strength is regulated by brain-derived neurotrophic factor. Mol Cell Neurosci. 2006;31:481-92.

33. Chang MC, Park JM, Pelkey KA, Grabenstatter HL, Xu D, Linden DJ, et al. Narp regulates homeostatic scaling of excitatory synapses on parvalbuminexpressing interneurons. Nat Neurosci. 2010;13:1090-7.

34. Hu JH, Park JM, Park S, Xiao B, Dehoff MH, Kim S, et al. Homeostatic scaling requires group I mGluR activation mediated by Homer1a. Neuron. 2010;68:1128-42.

35. Lee KJ, Lee Y, Rozeboom A, Lee JY, Udagawa N, Hoe HS, et al. Requirement for PIk2 in orchestrated ras and rap signaling, homeostatic structural plasticity, and memory. Neuron. 2011;69:957-73.

36. Sutton MA, Ito HT, Cressy P, Kempf C, Woo JC, Schuman EM. Miniature neurotransmission stabilizes synaptic function via tonic suppression of local dendritic protein synthesis. Cell. 2006;125:785-99.

37. Jakawich SK, Neely RM, Djakovic SN, Patrick GN, Sutton MA. An essential postsynaptic role for the ubiquitin proteasome system in slow homeostatic synaptic plasticity in cultured hippocampal neurons. Neuroscience. 2010;171:1016-31.

38. Anggono V, Clem RL, Huganir RL. PICK1 loss of function occludes homeostatic synaptic scaling. J Neurosci. 2011;31:2188-96.
39. House DR, Elstrott J, Koh E, Chung J, Feldman DE. Parallel regulation of feedforward inhibition and excitation during whisker map plasticity. Neuron. 2011;72:819-31.

40. Patino GA, Isom LL. Electrophysiology and beyond: multiple roles of $\mathrm{Na}+$ channel beta subunits in development and disease. Neurosci Lett. 2010;486:53-9.

41. Marionneau C, Carrasquillo Y, Norris AJ, Townsend RR, Isom LL, Link AJ, et al. The sodium channel accessory subunit Navbeta1 regulates neuronal excitability through modulation of repolarizing voltage-gated $\mathrm{K}(+)$ channels. J Neurosci. 2012;32:5716-27.

42. Balkowiec A, Katz DM. Cellular mechanisms regulating activity-dependent release of native brain-derived neurotrophic factor from hippocampal neurons. J Neurosci. 2002;22:10399-407.

43. Finkbeiner S, Tavazoie SF, Maloratsky A, Jacobs KM, Harris KM, Greenberg ME. CREB: a major mediator of neuronal neurotrophin responses. Neuron. 1997;19:1031-47

44. Arthur JS, Fong AL, Dwyer JM, Davare M, Reese E, Obrietan K, et al. Mitogen- and stress-activated protein kinase 1 mediates CAMP response element-binding protein phosphorylation and activation by neurotrophins. J Neurosci. 2004;24:4324-32.

45. Tonini R, Franceschetti S, Parolaro D, Sala M, Mancinelli E, Tininini S, et al. Involvement of CDC25Mm/Ras-GRF1-dependent signaling in the control of neuronal excitability. Mol Cell Neurosci. 2001;18:691-701.

46. Kim S, Ziff EB. Calcineurin mediates synaptic scaling via synaptic trafficking of Ca2 + -permeable AMPA receptors. PLoS Biol. 2014;12:e1001900.

47. Murphy TH, Blatter LA, Wier WG, Baraban JM. Spontaneous synchronous synaptic calcium transients in cultured cortical neurons. J Neurosci. 1992:12:4834-45.

48. Bengtson CP, Kaiser M, Obermayer J, Bading $\mathrm{H}$. Calcium responses to synaptically activated bursts of action potentials and their synapseindependent replay in cultured networks of hippocampal neurons. Biochim Biophys Acta. 1833;2013:1672-9.

49. Leslie KR, Nelson SB, Turrigiano GG. Postsynaptic depolarization scales quantal amplitude in cortical pyramidal neurons. J Neurosci. 2001;21:RC170.

50. Turrigiano GG, Leslie KR, Desai NS, Rutherford LC, Nelson SB. Activitydependent scaling of quantal amplitude in neocortical neurons. Nature. 1998;391:892-6.

51. Watt AJ, van Rossum MC, MacLeod KM, Nelson SB, Turrigiano GG. Activity coregulates quantal AMPA and NMDA currents at neocortical synapses. Neuron. 2000;26:659-70.

52. Gu N, Vervaeke K, Hu H, Storm JF. Kv7/KCNQ/M and HCN/h, but not KCa2/ SK channels, contribute to the somatic medium after-hyperpolarization and excitability control in CA1 hippocampal pyramidal cells. J Physiol. 2005;566:689-715.

53. Storm JF. Intracellular injection of a Ca2+ chelator inhibits spike repolarization in hippocampal neurons. Brain Res. 1987;435:387-92.

54. Storm JF. Potassium currents in hippocampal pyramidal cells. Prog Brain Res. 1990;83:161-87.

55. Shah MM, Migliore M, Valencia I, Cooper EC, Brown DA. Functional significance of axonal Kv7 channels in hippocampal pyramidal neurons. Proc Natl Acad Sci U S A. 2008;105:7869-74.

56. Yue C, Yaari Y. KCNQ/M channels control spike afterdepolarization and burst generation in hippocampal neurons. J Neurosci. 2004;24:4614-24.

57. Debanne D, Guerineau NC, Gahwiler BH, Thompson SM. Action-potential propagation gated by an axonal I(A)-like $\mathrm{K}+$ conductance in hippocampus. Nature. 1997:389:286-9.

58. Kole MH, Letzkus JJ, Stuart GJ. Axon initial segment Kv1 channels control axonal action potential waveform and synaptic efficacy. Neuron. 2007;55:633-47.

59. Guan D, Lee JC, Higgs MH, Spain WJ, Foehring RC. Functional roles of Kv1 channels in neocortical pyramidal neurons. J Neurophysiol. 2007;97:1931-40.

60. Geiger JR, Jonas P. Dynamic control of presynaptic $\mathrm{Ca}(2+)$ inflow by fastinactivating $\mathrm{K}(+)$ channels in hippocampal mossy fiber boutons. Neuron. 2000;28:927-39.

61. Ruppersberg JP, Schroter KH, Sakmann B, Stocker M, Sewing S, Pongs O. Heteromultimeric channels formed by rat brain potassium-channel proteins. Nature. 1990;345:535-7.

62. Rettig J, Heinemann SH, Wunder F, Lorra C, Parcej DN, Dolly JO, et al. Inactivation properties of voltage-gated $\mathrm{K}+$ channels altered by presence of beta-subunit. Nature. 1994;369:289-94. 
63. Schulte U, Thumfart JO, Klocker N, Sailer CA, BildI W, Biniossek M, et al. The epilepsy-linked Lgi1 protein assembles into presynaptic Kv1 channels and inhibits inactivation by Kvbeta1. Neuron. 2006;49:697-706.

64. Zhou YD, Lee $S$, Jin Z, Wright M, Smith SE, Anderson MP. Arrested maturation of excitatory synapses in autosomal dominant lateral temporal lobe epilepsy. Nat Med. 2009;15:1208-14.

65. Kim J, Jung SC, Clemens AM, Petralia RS, Hoffman DA. Regulation of dendritic excitability by activity-dependent trafficking of the A-type $\mathrm{K}+$ channel subunit Kv4.2 in hippocampal neurons. Neuron. 2007;54:933-47.

66. Hyun JH, Eom K, Lee KH, Ho WK, Lee SH. Activity-dependent downregulation of D-type K+ channel subunit Kv1.2 in rat hippocampal CA3 pyramidal neurons. J Physiol. 2013;591:5525-40.

67. Brown DA, Passmore GM. Neural KCNQ (Kv7) channels. Br J Pharmacol. 2009;156:1185-95.

68. Peters HC, Hu H, Pongs O, Storm JF, Isbrandt D. Conditional transgenic suppression of $\mathrm{M}$ channels in mouse brain reveals functions in neuronal excitability, resonance and behavior. Nat Neurosci. 2005;8:51-60.

69. Wu WW, Chan CS, Surmeier DJ, Disterhoft JF. Coupling of L-type Ca2+ channels to KV7/KCNQ channels creates a novel, activity-dependent, homeostatic intrinsic plasticity. J Neurophysiol. 2008;100:1897-908

70. Chung HJ, Jan YN, Jan LY. Polarized axonal surface expression of neuronal KCNQ channels is mediated by multiple signals in the KCNQ2 and KCNQ3 C-terminal domains. Proc Natl Acad Sci U S A. 2006:103:8870-5.

71. Pan Z, Kao T, Horvath Z, Lemos J, Sul JY, Cranstoun SD, et al. A common ankyrin-G-based mechanism retains KCNQ and NaV channels at electrically active domains of the axon. J Neurosci. 2006;26:2599-613.

72. Rasmussen HB, Frokjaer-Jensen C, Jensen CS, Jensen HS, Jorgensen NK, Misonou $\mathrm{H}$, et al. Requirement of subunit co-assembly and ankyrin-G for Mchannel localization at the axon initial segment. J Cell Sci. 2007;120:953-63.

73. Jensen HS, Grunnet M, Olesen SP. Inactivation as a new regulatory mechanism for neuronal Kv7 channels. Biophys J. 2007:92:2747-56.

74. Kaupp UB, Seifert R. Cyclic nucleotide-gated ion channels. Physiol Rev. 2002;82:769-824.

75. Gibson JR, Bartley AF, Huber KM. Role for the subthreshold currents ILeak and $\mathrm{IH}$ in the homeostatic control of excitability in neocortical somatostatin-positive inhibitory neurons. J Neurophysiol. 2006;96:420-32.

76. Campanac E, Daoudal G, Ankri N, Debanne D. Downregulation of dendritic I (h) in CA1 pyramidal neurons after LTP. J Neurosci. 2008;28:8635-43.

77. Williams SR, Stuart GJ. Site independence of EPSP time course is mediated by dendritic I(h) in neocortical pyramidal neurons. J Neurophysiol. 2000;83:3177-82

78. Berger T, Larkum ME, Luscher HR. High I(h) channel density in the distal apical dendrite of layer $V$ pyramidal cells increases bidirectional attenuation of EPSPs. J Neurophysiol. 2001;85:855-68.

79. Shao LR, Halvorsrud R, Borg-Graham L, Storm JF. The role of BK-type Ca2 + - dependent $\mathrm{K}+$ channels in spike broadening during repetitive firing in rat hippocampal pyramidal cells. J Physiol. 1999:521(Pt 1):135-46.

80. Uebele VN, Lagrutta A, Wade T, Figueroa DJ, Liu Y, McKenna E, et al. Cloning and functional expression of two families of beta-subunits of the large conductance calcium-activated K+ channel. J Biol Chem. 2000;275:23211-8

81. Berkefeld H, Fakler B, Schulte U. Ca2 + -activated K+ channels: from protein complexes to function. Physiol Rev. 2010;90:1437-59.

82. Gu N, Vervaeke K, Storm JF. BK potassium channels facilitate high-frequency firing and cause early spike frequency adaptation in rat CA1 hippocampal pyramidal cells. J Physiol. 2007;580:859-82.

83. Shin SM, Zhang N, Hansen J, Gerges NZ, Pak DT, Sheng M, et al. GKAP orchestrates activity-dependent postsynaptic protein remodeling and homeostatic scaling. Nat Neurosci. 2012;15:1655-66.

84. Wierenga CJ, Walsh MF, Turrigiano GG. Temporal regulation of the expression locus of homeostatic plasticity. J Neurophysiol. 2006;96:2127-33.

85. Ramocki MB, Zoghbi HY. Failure of neuronal homeostasis results in common neuropsychiatric phenotypes. Nature. 2008;455:912-8.

86. Bolstad BM, Irizarry RA, Astrand M, Speed TP. A comparison of normalization methods for high density oligonucleotide array data based on variance and bias. Bioinformatics. 2003;19:185-93.

87. Lönnstedt I, Speed TP. Replicated microarray data. Stat Sinica. 2002;12:31-46.

88. Benjamini Y, Hochberg Y. Controlling the false discovery rate: A practical and powerful approach to multiple testing. J R Statist SOC. 1995;57:289-300.
89. Gentleman RC, Carey VJ, Bates DM, Bolstad B, Dettling M, Dudoit S, et al. Bioconductor: open software development for computational biology and bioinformatics. Genome Biol. 2004;5:R80.

90. Smyth GK. Linear models and empirical bayes methods for assessing differential expression in microarray experiments. Stat Appl Genet Mol Biol. 2004;3:Article 3.

91. da Huang W, Sherman BT, Lempicki RA. Systematic and integrative analysis of large gene lists using DAVID bioinformatics resources. Nat Protoc. 2009;4:44-57.

92. Bolton EC, So AY, Chaivorapol C, Haqq CM, Li H, Yamamoto KR. Cell- and gene-specific regulation of primary target genes by the androgen receptor. Genes Dev. 2007;21:2005-17.

93. Chung HJ, Qian X, Ehlers M, Jan YN, Jan LY. Neuronal activity regulates phosphorylation-dependent surface delivery of $G$ protein-activated inwardly rectifying potassium channels. Proc Natl Acad Sci U S A. 2009;106:629-34.

\section{Submit your next manuscript to BioMed Central and take full advantage of:}

- Convenient online submission

- Thorough peer review

- No space constraints or color figure charges

- Immediate publication on acceptance

- Inclusion in PubMed, CAS, Scopus and Google Scholar

- Research which is freely available for redistribution 